\title{
Role of platelets in neuroinflammation: a wide-angle perspective
}

\author{
Lawrence L Horstman', Wenche Jy', Yeon S Ahn', Robert Zivadinov², Amir H Maghzi', Masoud Etemadifar ${ }^{3}$, \\ J Steven Alexander ${ }^{4}$, Alireza Minagar ${ }^{5^{*}}$
}

\begin{abstract}
Objectives: This review summarizes recent developments in platelet biology relevant to neuroinflammatory disorders. Multiple sclerosis (MS) is taken as the "Poster Child" of these disorders but the implications are wide. The role of platelets in inflammation is well appreciated in the cardiovascular and cancer research communities but appears to be relatively neglected in neurological research.
\end{abstract}

Organization: After a brief introduction to platelets, topics covered include the matrix metalloproteinases, platelet chemokines, cytokines and growth factors, the recent finding of platelet PPAR receptors and Toll-like receptors, complement, bioactive lipids, and other agents/functions likely to be relevant in neuroinflammatory diseases. Each section cites literature linking the topic to areas of active research in MS or other disorders, including especially Alzheimer's disease.

Conclusion: The final section summarizes evidence of platelet involvement in MS. The general conclusion is that platelets may be key players in MS and related disorders, and warrant more attention in neurological research.

\section{Introduction}

Platelets have long been implicated, or at least been suspected, in the etiology of a variety of neuropathologies, most obviously including ischemic stroke but also others such as multiple sclerosis (MS). In recent decades, a series of discoveries have been made which place those conjectures on a sound rational footing. Broadly speaking, the essence of these findings is that platelets possess an unexpectedly large variety of receptors and secretory products, additional to those serving their classical role in hemostasis and thrombosis, which are active in inflammation, immunity, and tissue repair. This versatility is remarkable in view of their very small size and lack of cell nuclei. Indeed, in the early days they were regarded as nothing more than cellular debris. These recent advances, together with the fact that platelets are often the first cells to arrive at sites of vascular injury, suggest the hypothesis that they may be central players in neurodegenerative diseases.

As the title states, this review provides a wide-angle perspective on platelets as mediators of inflammation

\footnotetext{
* Correspondence: aminag@|suhsc.edu

${ }^{5}$ Department of Neurology, Louisiana State University Health Sciences Center, Shreveport, LA 71130, USA
}

and immunity, with emphasis on neurological implications. Therefore, it is not possible to treat each topic in the depth it deserves. Most of the topics are large and specialized fields in themselves with their own wealth of literature. However, the references supplied will lead the interested reader to more comprehensive accounts. Some good reviews of platelets in inflammation are available [1] but the present review is more wide-ranging and exhibits the relevance to neurology specifically at every opportunity.

\section{Platelet basics}

Platelets, properly termed thrombocytes, were traditionally considered to function exclusively in hemostasis and thrombosis, a role for which they are superbly adapted. Platelets are produced as fragments of megakaryocytes and, according to the convincing arguments of Martin [2], this fragmentation occurs during passage through the lungs. Like erythrocytes, they lack nuclei but unlike erythrocytes they do possess mitochondria. They are about $1 / 4$ the diameter of erythrocytes and about $1 / 24$ as numerous, but they preferentially circulate along the vessel wall [3], positioning them to respond immediately to vascular injury.

\section{Biomed Central}

(c) 2010 Horstman et al; licensee BioMed Central Ltd. This is an Open Access article distributed under the terms of the Creative Commons Attribution License (http://creativecommons.org/licenses/by/2.0), which permits unrestricted use, distribution, and reproduction in any medium, provided the original work is properly cited. 
All blood cells undergo activation in response to a rise in intracellular calcium but platelets are most spectacular in this response, transforming irreversibly within seconds from the resting discoid shape to extend numerous pseudopodia, and becoming highly adhesive to each other (aggregation), to other cells, and to almost any surface, notably on collagen exposed in the subendothelium, to form a platelet plug (white clot) [4]. However, weak agonists can induce partial and reversible activation ("priming"), which can be augmented synergistically by other agents via multiple pathways, and this primed state has been considered a target for drug intervention [5]. Platelet activation is also accompanied by secretion, i.e. the release of numerous substances from specialized granules, as listed in Table 1 and a list of acronyms and alternative names of various substances related to platelets is presented in Table 2. A list of major platelet glycoproteins is given in Table 3 and Table 4 lists the principal natural agonists of platelets and the receptors on which they act.

Equally important is the ability of activated platelets, and microparticles from them which are released concomitantly, to catalyze the coagulation cascade. This is accomplished by an activation-dependent membrane inversion or "flip-flop" by which normally in-facing phospholipids (PL) become exposed to plasma [6]. These PLs are mainly anionic, such as phosphatidylserine (PS), and render the membrane procoagulant by promoting assembly of the vitamin $\mathrm{K}$-dependent coagulation factors into their active complexes (prothrombinase and factor $\mathrm{X}$-ase), to generate the thrombin that converts fibrinogen to the fibrin plug. The role of vitamin $\mathrm{K}$ in this process is to serve as a cofactor for the post-translational addition of an extra carboxy group to glutamic acid residues (Gla domains), enabling them to bind calcium, much as citrate does, thereby anchoring the coagulation factors to suitable PL membrane surfaces (such as PS) via calcium bridging.

Since hemostasis and thrombosis is not the focus of this article, readers wishing more depth are referred to standard textbooks of hematology [7-10] or more specialized books [11].

\section{Introduction to platelets as inflammatory mediators}

It had become clear by 1995 that platelets also play major roles in inflammation and immunity [12-15]. This concept was amply confirmed and extended by subsequent findings [16], beginning with the discovery around the same time of the first chemokine receptor on platelets (referenced below). The following paragraphs briefly review the major classes of platelet-derived factors which are active in inflammatory states, with emphasis on implications for neurological disorders.

\section{Matrix metalloproteinases in platelets}

The matrix metalloproteinases (MMPs) are a group of about 40 homologous proteases which are secreted to the extra-cellular matrix (ECM) in an inactive form. As a group these enzymes depend on a metal ion for activity, generally zinc. A subgroup of these enzymes, the membrane-type (MT-MMP), remains at the plasma membrane and can activate the secreted forms of the enzyme. Other closely related enzymes are those of the

Table 1 Main Constituents of Platelet Secretory Granules

\begin{tabular}{|c|c|}
\hline \multicolumn{2}{|l|}{ Dense Granules } \\
\hline Solutes & 5HT, ADP, ATP, GDP, GTP, Ca, Mg, PyroPi, histamine \\
\hline Membrane & CD62P, CD63, GP's Ib \& IIb/IIla, LAMP2, Src, Ral-1 \\
\hline Adhesive glycoproteins & fibronectin, vitronectin, VWF, TSP \\
\hline Proteoglycans & PF4, BTG, serglycin, HRGP \& BTG Ag's: PBT, CTAP-III, NAP-2 \\
\hline Mitogens: & PDGF, TGFß, ECGF, EGF, VEGF, VPE, IGF, IL-ß \\
\hline Protease inhib's & TFPI, PAI-1, PDCl, $\alpha_{2}$-antiplasmin, C1 inhibitor, $\alpha_{2}$-antitrypsin, $\alpha_{2}$-macroglobulin \\
\hline Coagulation: & Factors V, XI, XIII, HMWK, fibrinogen, PAI-1, protein C, protein S, protein C inhibitor, TSP-1, TSP-2 \\
\hline Membrane* & CD9, CD31, CD36, CD62P, CD144, GLUT-3, \\
\hline & * Not including several GP's found also on plasma membrane \\
\hline & IgG, IgM, IgA, albumin, GP la/multimerin, osteonectin, clusterin, angiostatin, endostatin, plasminogen \\
\hline $\begin{array}{l}\text { Lysosomal Granules } \\
\text { (Lysosomes) }\end{array}$ & \\
\hline Acid proteases & cathepsins D \& E, carboxypeptidases A \& B, collagenase, acid phosphatase, aryl sulfatase \\
\hline Glycohydrolases & $\begin{array}{l}\text { heparinase, b-galactosidase, b-glucuronidase, b-N-acetyl-glucosaminodase, b-glycerophosphatse, b-D-glucosidase, a- } \\
\text { D-glucosidase, a-L-fucosidase, b-D-fucosidase, a-L-arabinosidase, a-D-mannosidase }\end{array}$ \\
\hline Membrane & LIMP-1, LAMP-1, -2 \\
\hline Dense Tubules & Principal Ca store for internal secretion \\
\hline
\end{tabular}

Contents of the three main granules (dense, alpha, lysosomal) and the "dense tubules" are listed in Table 1. 
Table 2 Main Constituents of Platelet Secretory Granules

\begin{tabular}{|c|c|c|c|}
\hline \multicolumn{4}{|c|}{ Acronyms } \\
\hline $5 \mathrm{HT}$ & serotonin; 5-hydroxytryptamine & NAP-2 & neutrophil activating peptide- 2 \\
\hline ADP, ATP & adenosine diphosphate, -triphosphate & PADGEM & GMP-140. Former names for CD62P \\
\hline CD144 & Glut 3 & PAl-1 & plasminogen activator inhibitor 1 \\
\hline CD36 & GP IV & PBP & platelet basic protein \\
\hline CD62P & P-selectin; see also PADGEM & $\mathrm{PDCl}$ & platelet-derived collegenase inhibitor \\
\hline CTAP-III & connective tissue activating protein III & PDGF & platelet-derived growth factor \\
\hline EC & endothelial cell & PDGF & platelet-derived growth factor \\
\hline ECGF & endothelial cell growth factor & PECAM & CD31; platelet-EC adhesion molecule \\
\hline EGF & epidermic growth factor & PF4 & platelet factor 4 \\
\hline Gbp & guanine binding protein & BTG & beta thromboglobulin \\
\hline GDP, GTP & guanine diphosphate, -triphosphate & TFPI & tissue factor pathway inhibitor \\
\hline HMWK & high molecular weight kininogen & TGFß & transforming growth factor $ß$ \\
\hline HRGP & histidine-rich glycoprotein & TSP & thrombospondin \\
\hline IGF & insulin-like growth factor & VEGF & vascular endothelial growth factor \\
\hline LAMP1, 2 & Iysosomal associated membrane prot & VPF & vascular permeability factor \\
\hline LIMP, CD63 & lysosomal integral membrane protein & vWF & von Willebrand factor \\
\hline NAP-2 & neutrophil activating peptide-2 & & \\
\hline
\end{tabular}

The standard abbreviations used are spelled out in Table 2. The contents of each are classified in accordance with most of the sources. The main source was Ch. 7 of Gresele et al [11], with some updates from other sources such as [1]. Similar tables appear are found in textbooks of hematology but details may differ. For example, Table twenty four to three of Colman et al [10] lists about twice as many acid hyrdrolases of the lysosomes. No attempt was made to give a complete listing, i.e. many agents cited in text are not listed here. More details can be found in more recent or specialized sources such as [318]. The subcellular localization of some recently identified secreted substances may not yet be known. Many proteins of the platelet plasma membrane are also found on the membranes of granules and in the invaginations of the membrane known as the open canalicular system (OCS).

ADAM's ( $A$ Distintegrin And Metalloprotease) and the ADAMTS's (ADAM with ThromboSpondin domain) $[17,18]$. Many are also known by their earlier common names. They have varying degrees of substrate specificity towards many proteins in the vicinity of the ECM including collagen, fibronectin, gelatin, laminin and other stromal components ("stromelysins"). Accordingly, their activities must be finely controlled and regulated by the aforementioned activators, specific inhibitors known as TIMP's (Tissue Inhibitor of $M M P$ ), and by the circulating plasma protein, alpha-2-macroglobulin. MMPs are important in many aspects of human development and tissue remodeling, and play significant roles in pathogenesis of neuroinflammatory disorders.

MMPs have been generally recognized as major participants in disruption of the blood-brain barrier (BBB) in MS [19] and there is persuasive evidence that they play a direct causal role [20]. This evidence consists of close association of rising levels, particularly of MMP-9, prior to onset of exacerbations in humans and in the animal model of MS known as experimental autoimmune encephalomyelitis (EAE) [21-23]. Relative reduction of TIMP's was also seen. In EAE model, disease severity is sharply attenuated by inhibition of MMP or by gene knockout. Similar results were observed with an alternative model of MS, demyelinating canine distemper virus infection [24]. In human immunodeficiency virus (HIV) infection, MMP-9 in particular was implicated in disruption of the BBB [25]. MMPs have also been implicated in post-ischemic brain injury [26]. MMP-9 may be particularly noxious [27] but MMP-2 is also discussed as a biomarker [28], as are others for the case of MS [20]. The mechanism usually proposed is that infiltrating leukocytes employ MMPs to disintegrate the basement membranes of cerebral endothelial cells to enter the CNS.

Accordingly, inhibitors of MMPs are under active investigation for treatment of MS and some other neuropathologies [29]. At least one action of tetracycline derivatives such as minocycline and doxycycline is inhibition of MMPs [30-32]. Indeed, interferon-beta1a (IFNbeta) is reported to have such action $[33,34]$. On the other hand, several groups caution against prolonged and non-specific inhibition of MMPs for therapy because of their equally prominent role in repair, recovery and normal CNS health [35-37].

How might platelets be placed in these events? First, platelets have been shown to express MMPs -1, -2, -3 , -9; ADAM-10, -17; all four TIMP's except TIMP-3; MT1-MMP (also known as MMP-14); and ADAMTS-13 $[38,39]$. The cited review [38] is up-to-date but limits discussion to the role of MMPs in platelet function and does not explore the likely effects of MMPs secreted during platelet activation on bystander cells, analogous to the manner in which neutrophils or glial cells can injure neurons in the vicinity [40]. Second, platelets are 
Table 3 Platelet surface glycoproteins (GP's) and agonists

\begin{tabular}{|c|c|c|c|}
\hline \multirow[b]{2}{*}{ Classical } & \multirow[b]{2}{*}{ CD \# } & \multicolumn{2}{|c|}{ Major Platelet Glycoprotein (GP) Receptors } \\
\hline & & Integrin & Activating Ligand(s) \\
\hline$\overline{G P}\|\mathrm{~b} /\| \mathrm{lla}$ & CD41b & $\alpha_{\| 1 \mathrm{~b}} \beta_{3}$ & $\begin{array}{l}\text { Fibrinogen, vWF, fibronectin, } \\
\text { vitronectin }\end{array}$ \\
\hline GP Ib-IX & $\begin{array}{l}\text { CD42a,b, } \\
\text { c }\end{array}$ & & vWF, thrombin \\
\hline GP la-lla & CD49b & $\alpha_{2} \beta_{1}$. & Collagen \\
\hline GP Ic-lla & CD49e & $\alpha_{5} \beta_{1}$. & Fibronectin \\
\hline GP Ic-lla & CD49f & $\alpha_{6} ß_{1}$. & Laminin \\
\hline Vitronectin & & $\alpha_{\vee} \beta_{3}$ & $\begin{array}{l}\text { Vitronectin, VWF, fibronectin, } \\
\text { fibrinogen, TSP }\end{array}$ \\
\hline PECAM-1 & CD31 & & Further interaction with endothelium \\
\hline P-selectin* & CD62P & & Interaction with leukocytes \\
\hline \multicolumn{4}{|c|}{ * a.k.a. PADGEM or GMP-140 in the older literature. } \\
\hline \multicolumn{4}{|c|}{ Listed: Ib, Ila, IIb, IIla, IIlb (a.k.a. GP IV, CD36), V, IX. } \\
\hline
\end{tabular}

The classical GP designations (which are based on location in electrophoresis) are given in the first column and the antigen CD numbers in the 2 nd column The 3rd column gives the newer integrin names, which are compounded of two subunit types $(\alpha, \beta)$. Integrin nomenclature is awkward, hence the classical names remain in wide use. Many of the GP's are known also by other names, e.g. VLA-2, $-3,-5,-6$ (for "very late antigens") corresponding respectively to integrins $\alpha_{2} \beta_{1}, \alpha_{3} \beta_{1}, \alpha_{5} \beta_{1}$ (or $\alpha_{v} \beta_{1}$ ), and $\alpha_{6} \beta_{1}$. The 4 th and last column gives the ligands which activate platelets via those GP receptors, and if more than 1 is given, they are in order of potency. For example, the complex GP Ib-IX is the main site for vWF but it has some activity for other GP sites, and likewise collagen. In most cases there is evidence of receptor mobility, clustering, interaction, synergy and inter-dependence, as noted for Table 4. Data adapted from Table 22.1 and others in Colman et al [10].

often the first responders to sites of injury or inflammation. Third, it is known that platelets can interact with leukocytes to form circulating complexes, first demonstrated by Rinder et al $[41,42]$, extended by our laboratory to platelet microparticles (PMP) [43], and now widely employed as an assay of activated or inflammatory states, e.g. [44-47]. It has been shown that formation of platelet-leukocyte complexes is associated with the expression and activation of MMPs $-1,-2,-3$ and -9 [48]. It is not clear in that paper if the source of MMP is platelets or leukocytes (it is likely both) but inhibitors of MMP in the media reduced formation of the complexes while active MMP promoted them.

Fourth, is the effect of platelet-derived microparticles (PMP). Although little work of a specifically neurological nature has been done in this area, cancer researchers have demonstrated that PMP strongly promote the invasive potential of prostate and breast cancer cells in a manner dependent on MMP expression [49-51], a process resembling leukocyte infiltration to the CNS. PMP express most of the platelet membrane proteins, therefore likely including MT-1 MMP, which was notable in the study [51]. The work by Jy et al of our laboratory demonstrated that PMP can directly activate and bind to neutrophils [43]; however, MMP activities were not measured. We have recently presented evidence that cell-derived microparticles, especially PMP, may play an important role in neurodegenerative diseases [52,53]. Although studies of platelet activation in MS are rare in the recent literature, the data of Cananzi et al from patients in remission clearly demonstrate chronic platelet activation in MS [54] (their figure two), confirming earlier reports, which they cite, and which we discuss in the closing section of this paper.

\section{Platelet chemokines}

Chemokines are central to inflammation chiefly by signaling leukocyte migration/infiltration and differentiation, but also by other actions [55]. About 50 are known and half as many receptors. They are low molecular weight proteins (7-12 kDa) and are known both by acronyms for their common names and by systematic nomenclature, the latter consisting of two main groups, $\mathrm{CC}$ and $\mathrm{CXC}$, and a few exceptions. These symbols refer to the amino acids (aa), Cys-Cys or Cys-X-Cys where X is any other aa. Suffix L for "ligand" or R for "receptor" is applied. The alpha chemokines are the CXCL's and beta chemokines are the CCL's. In general, the CCL's bind only to CCR's, while CXCL's bind only to CXCR's. Beyond that, the receptors are promiscuous to varying degrees, suggesting complex and subtle signaling depending on relative concentrations and affinities of the ligands present.

The discovery of the first chemokine receptors on platelets around 1995 by Power et al [56-58] was a watershed in platelet biology. This was followed by a succession of advances (e.g. [59-61]), leading to the present knowledge of platelet chemokines, reviewed in 2003 [62], 2007 [63] and 2008 [64]. The 2007 review is particularly clear but each brings out novel points. Platelet factor 4 (PF4), now called CXCL4, was the first known chemokine (though not originally so named) and is secreted in abundance from the alpha granules, along with about 10 other platelet chemokines. In Table 5 a list of platelet chemokines and responses to them is presented. Most of the work on platelet chemokines has been orientated to cardiovascular disease. Useful insights might be gained from tissue co-culture of brain endothelia with astrocytes (model of BBB) to study the role of platelets in leukocyte adhesion, transmigration, and other phenomena relevant to neuroinflammatory diseases.

Meanwhile, recent advances have created more complexity, not simplification. It should be noted that our knowledge of platelet chemokines and receptors for them is based largely on murine studies and tissue culture with limited cell types. For example, human umbilical vein endothelial cells (HUVEC) are widely used because they are easy to obtain and grow, but they often exhibit quite different responses compared to brain micovascular EC, as we have observed in microparticle studies [65] and pointed out for in vitro 
Table 4 Platelet surface glycoproteins (GP's) and agonists

\begin{tabular}{|c|c|c|c|c|c|c|c|}
\hline & Main Platelet Agon & & & & & & \\
\hline & Agonist & Receptor(s) & & Integrin(s) & & For GPCR's: & \\
\hline \multirow[t]{2}{*}{ Strongest } & Thrombin + collager & & & & & & \\
\hline & $\mathrm{A} 23187^{*}$ & & & - & & & \\
\hline \multirow[t]{3}{*}{ Strong } & Thrombin & PAR1 & PAR4 & $\alpha_{\| b} \beta_{3}$ & $\alpha_{2} \beta_{1}$ & & \\
\hline & Collagen & & & & & & \\
\hline & PAF & & & & & & \\
\hline \multirow[t]{2}{*}{ Medium } & ADP & $P 2 Y_{1}$ & $P 2 Y_{12}$ & & & $\mathrm{G}_{\mathrm{q \alpha}}$ & \\
\hline & $\mathrm{TXA}_{2}$ & $T P-\alpha,-\beta$ & & & & $\mathrm{G}_{\mathrm{q}}$ & $\mathrm{G}_{12}$ \\
\hline \multirow[t]{4}{*}{ Weak } & Epinephrine & & & & & & \\
\hline & Arachidonate & & & & & & \\
\hline & Vasopressin & & & & & & \\
\hline & Serotonin & & & & & & \\
\hline \multirow[t]{2}{*}{ Damping } & Prostacyclins & IP R & $E P_{2} \mathrm{R}$ & & & & \\
\hline & PACAP, VIP & VPAC R & & & & $\mathrm{G}_{s \alpha}$ & \\
\hline
\end{tabular}

Listing of the main primary platelet agonists in approximate order of potency, and their receptors types, e.g. PAR $=$ Protease-Activated Receptor. Other abbreviations are listed below. By "primary" is meant having direct action. For example, fibrinogen and vWF (Table 1) do not bind or activate the normal resting platelet. The third column lists the integrin names and the last column indicates some which are known to be GPCR's (= G-Protein Coupled Receptor). Similar listings appear in many sources. The relative potency may be misleading since it is based on data in vitro whereas in vivo several of these agonists, especially the "weak" ones, can act synergistically to potentiate or "prime" responses to others [5]. For example, serotonin [266,319]; and vWF-induced aggregation requires costimulation (including by ristocetin, an antibiotic used in laboratory studies) or conformation change of vWF. Information on the GPCR's is simplified from Ch. 107 of Hoffman et al [8] with terminology updated according to Van Geet et al [320]. The "damping" agonists shown at bottom inhibit activation by raising cAMP (cyclic AMP) levels, which is opposite the usual effect of cAMP elevation in other cells. These tables are for orientation only. Other abbreviations (see also Table 2): $\mathrm{TXA}_{2}=$ thromboxane $\mathrm{A}_{2} ; \alpha_{2 \mathrm{~A}} \mathrm{AR}=\mathrm{a}_{2 \mathrm{~A}}$-adrenergic receptor; PACAP = pituitary adenylyl cyclase activating peptide; VIP $=$ vasointestinal peptide; prostacyclins refer to prostaglandins such as $\mathrm{PGE}_{1}, \mathrm{PGI}_{2}$.

studies of antiphospholipid antibodies [66]. Endothelial cell (EC) activation is not a simple yes/no effect but a multi-pathway phenomenon having both immediate effects (within seconds of stimulation, such as CD62E cell surface expression) and slower effects (24-48 hr) that depend on genetic upregulation of the pathways activated by, for example, exposure to TNF- $\alpha[67,68]$.

Some unwarranted conclusions about platelet chemokines have been put forth. Geissner suggests [64] that only platelet CXCL4 (PF4) and CXCL7 are likely to be important since other cells are richer sources of the remaining platelet chemokines, and some platelet chemokines are acquired from plasma (Table 6). This implies that the other platelet chemokines are inconsequential, and overlooks the fact that platelets are often the first cells to arrive at a site of vascular injury, and are exceptionally responsive to stimuli. Therefore, platelets may indeed be an important source in the microenvironment of all chemokines they carry, as has been noted by Baltus et al for monocyte recruitment [69]. Full discussion of the platelet chemokine system is beyond the scope of this review, while our purpose is limited to raising awareness of the new face of platelet biology. However, to add dimension, notes on a few of the platelet chemokines follow. Chemokines involved with repair and recovery are considered in the next section. For surveys of chemokines particularly relevant to MS, see [70,71].

\section{Rantes}

This has long been recognized in platelets [60,72]. It was suspected of being carried on platelet microparticles [73] and that was subsequently confirmed [74]. Gene polymorphisms for this chemokine (CCL5) and one of its receptors (CCR5) affect the susceptibility, severity, and age of onset of MS [75]. Ubogu et al found that mononuclear cell migration across an in vitro model of the BBB was driven by CCL5, being inhibited by antibodies against it [76,77]. That leukocyte infiltration is driven by CCL5 gained further support by the clinical and laboratory observations of Jalosinski et al [78]. At least one novel drug is in the pipeline which targets CCR1 (another receptor for CCL5) for therapy of MS and other inflammatory disorders [79]. Similar findings on the importance of RANTES are seen in EAE models [80-83]. This sampler of literature makes clear that CCL5 is important in MS. However, the participation of platelets as source of these cytokines is not considered in these papers, nor are platelets present in the in vitro studies, though it is clear that platelets are potentially important players.

\section{Trem}

This does not have the structure of a true chemokine receptor but is included here because of its role in inflammation. Named as the Triggering Receptor Expressed on Myeloid cells (TREM), it was discovered in 2000, was identified on platelets soon after, and is only 
Table 5 Platelet chemokines and receptors

\begin{tabular}{|c|c|c|c|}
\hline \multicolumn{3}{|c|}{ Platelet Chemokines and Receptors } & \multirow[b]{2}{*}{ Platelet Chemokine Receptors } \\
\hline Platelet Chemokine & Common Name & Receptor(s) & \\
\hline CXCL1 & $\mathrm{GRO}-\alpha$ & CXCR2>CXCR1 & CCR1 \\
\hline CXCL4 & PF4 & CXCR3B, GAG & CCR3 \\
\hline CXCL4L1 & PF4alt & unknown & CCR4 \\
\hline CXCL5 & ENA-78 & CXCR2 & CXCR4 \\
\hline CXCL7 [a] & NAP-2 & CXCR2>CXCR1 & CX3CR1 \\
\hline CXCL8 & IL-8 & CXCR1, CXCR2 & \\
\hline CXCL12 & SDF-1 $1 \alpha$ & CXCR4 & \\
\hline CCL2 & MCP-1 & CCR2 & (Those which are disputed are not shown) \\
\hline CCL3 & MIP-1 $\alpha$ & CCR1, 2, 3 & \\
\hline $\mathrm{CCL} 5$ & RANTES & CCR1, 3, 4, 5 & \\
\hline CCL17 & TARC & CCR4, CCR8 & \\
\hline
\end{tabular}

Platelet chemokines and their common names are listed at left, then their receptors, not all of which are present on platelets. Those which are present on platelets are listed in the right-most column. As noted in text, there is considerable promiscuity of chemokines towards the receptors, some being more specific than others.

Acronyms for common names of chemokines that activate platelets: CCL17 (TARC): thymus and activating-regulating chemokine; CCL22 (MDC): macrophage-derived chemokine; CXCL12 (SDF-1): stromal cell-derived factor 1alpha; CCL18 (PARC): pulmonary and activation regulated chemokine.

recently being understood [84,85]. Initial reports were that it was pro-inflammatory, then TREM-2 was identified and appeared to act oppositely (anti-inflammatory). Current thinking is that all three known TREM's act to integrate many kinds of signals, in concert with DAP-12 as a complex. A soluble form also exists. The main known triggering ligand is the TREM-Like Transcript 1 (TLT-1), which inhibits thrombin-induced platelet activation [86], is secreted from platelet $\alpha$-granules [87], and modulates neutrophil activation [88] and probably other leukocytes. Because of its seeming role as a kind of "master integrator" of pro- and anti-inflammatory signals ("mixed messages"), it is of great interest in neuroinflammatory conditions such as MS, as referenced [85]. Here again, the possible contribution of platelets to TREMmediated events is rarely mentioned.

Platelet factor 4 (PF4; CXCL4)

PF4 was discovered early (1977) and is secreted in abundance from platelets upon activation. Accordingly,

Table 6 Processing of CXCL7

\begin{tabular}{cl}
\hline & Processing of CXCL7 \\
$\downarrow$ pro-PBP & pro-Platelet Basic Protein \\
PBP & Platelet Basic Protein \\
$\downarrow$ & \\
CTAP-III & Several actions \\
$\downarrow$ & \\
$\beta$-TG & Several actions \\
$\downarrow$ & \\
NAP-2 & Most pronounced actions \\
\hline
\end{tabular}

This shows steps in the processing of CXCL7, which is unusual in having distinctive activities at each step. its measurement has been taken as an index of platelet activation, such as in MS [54]. As a chemokine, it is unusual in several ways. It does not exert chemotaxis for any cell yet tested but a large number of other activities have been attributed to it (see Table 2 of [63]). Indeed, the list of actions is so lengthy that some have doubted the specificity of PF4 effects. A possible solution to this "embarrassment of riches" is the hypothesis set forth by Sachais et al [89], that the true function of PF4 is not specific signaling but is to neutralize electric charge on glycosaminoglycans (GAG's), as this could well explain the majority of its reported actions. (Recombinant PF4 reached clinical trials as an alternative to protamine sulfate for neutralizing heparin [90].) Clinically, PF4 is best known as the target antigen of heparin-induced thrombocytopenia (HIT); that is, the IgG of HIT is directed against PF4, not heparin per se [91]. Intriguing parallels have been drawn between HIT and anti-phospholipid syndrome (APS) [92], and between APS and MS, as we have referenced [66].

\section{Platelet cytokines and growth factors}

The cytokines constitute a lengthier list of signaling molecules, notably including the interleukins, and overlaps somewhat with the chemokines. Some helpful summary tables (such as distributed by R\&D Systems) include both groups, and a number of members are commonly listed in both families, e.g. interleukin 8 (IL8) is now CXCL8, and RANTES, once considered a cytokine, is now assigned as CCL5. Originally, a sharp distinction was drawn between factors that attracted leukocytes (chemokines) and factors with other effects (cytokines, e.g. the interleukins) but that distinction is 
increasingly blurry in view of the pleiotropic actions of so many of these substances.

As the first cells to arrive on the scene of vascular injury, it makes sense that platelets would be involved with tissue repair as well as plugging leaks. Accordingly, some of the most informative reviews of platelet cytokines are oriented to the role of platelets in wound healing [93-95]. One may suspect important roles in neurological tissue repair as well. The 2008 review by Nurden's group [94] includes dozens of factors in addition to the chemokines listed above. Although no attempt will be made to list them here, the platelet "growth factors" include EGF, TGF- $\beta 1,-\beta 2$, PDGF, HGF, FGFb (FGF-2), and a series of pro- and antiangiogenic factors, e.g., VEGF-A, -C. Platelets also secrete the antimicrobial peptides known as thrombocidins. Of special interest in neurology is the presence of semaphorin 3A (a.k.a. collapsin-1), another of many "CNS-specific" agents found in platelets. Also listed in [94] are the cytokines TRAIL, LIGHT, SDF-1 $\alpha$, HMGB1 , etc., and the interleukins $1 \mathrm{~L}-8$ and IL-6sR in platelets. Their review misses a few, notably IL-1 from platelets $[96,97]$, which is secreted on platelet microparticles. Further discussion of these platelet-derived agents (which are difficult to neatly classify) is beyond the scope of this review, our purpose being to bring to wider attention the astonishing variety of bioactive platelet-derived agents. The following few examples may not be widely appreciated.

\section{CD40 and CD40 ligand (CD40L, a.k.a. CD154)}

Platelets are the main source of CD40L, secreting it to deliver co-stimulatory signals to antigen-presenting cells (APC's) [98-100]. Of note, platelets can induce maturation and activation of dendritic cells (DC) [101,102], but probably involving more than CD40L alone [103]. The role of CD40L in MS is well appreciated in reviews $[104,105]$ and is a target of new therapies $[106,107]$. Filion et al report that CD40L levels on monocytes were highest in secondary progressive MS (SPMS) [108]. Harp et al demonstrated that CD40L/IL-4 as well as another stimulating reagent induced $\mathrm{B}$ cells to upregulate CD80 and HLA-DR; however, only CD40L/IL-4 was effective in eliciting CNS-antigen specific proliferation by autologous T cells [109]. CD40L is perhaps best known for other putative actions which make it a risk factor in cardiovascular disease [110], although somewhat controversially.

An important technical issue arises with CD40L. Prior to about 2005, and often yet today, circulating levels of CD40L were measured in serum by standard ELISA kits. We reported in 2004 [111] that serum levels are largely an artifact of platelet activation during blood clotting, being from 10 -fold to 50 -fold higher than in plasma specimens. This was subsequently confirmed by at least two other groups, and the kit makers have since changed their instructions to advise use of plasma, not serum for assay. In view of this, one must question the significance of reports based on serum assays, since serum levels reflect the total releasable platelet CD40L, not the true plasma level. It appears that this is not yet fully appreciated since several reviews make no mention of it and accept earlier reports on the same footing as more recent studies that measure plasma levels. Moreover, one may expect similar artifacts for other chemokines secreted from platelets if measured in serum, especially PF4, but also the others since nearly all will be released to serum as an artifact of clotting, inflating true plasma levels.

\section{Toll-like receptors on platelets}

The discovery of toll-like receptors (TLRs) on platelets in 2004 was another completely unexpected development. Other immune functions of platelets had been earlier noted, including generation of killer-like reactive oxygen species (ROS) [13], phagocytic activity, secretable antimicrobials (thrombocidins), interactions with leukocytes and endothelial cells by direct contact or secretory signaling, and as the principal source of CD40L (CD154) [100,110].

First discovered in the fruit fly, about a dozen TLR's are now known and each is tuned to recognize a distinct class of pathogen-associated molecular patterns (PAMP's). The PAMP's which are recognized include bacterial components such as flagellin, lipopolysaccharide (LPS), lipoproteins, peptidoglycans, certain regions of DNA, and so on. The true TLR's are transmembrane surface proteins, but proteins with similar PAMP-recognition functions for virions occur in the cytoplasm $[112,113]$. The membrane TLR's, some of which function as heterodimers (e.g. TLR2 plus TLR1 or TLR6), upon engagement with ligand, pass their signals through a series of accessory transducers to the cell nucleus where antimicrobial genes are activated to yield products such as IL- 1 and TNF- $\alpha$. Since platelets lack nuclei, however, they seemed irrelevant to studies of the tissue distribution of TLR's.

To our knowledge, it was Shiraki et al who discovered the first TLR's in platelets, TLR1 and TLR6, by mRNA, Western blotting, and flow cytometry [114]. Furthermore, their expression was upregulated in response to IFN $-\gamma$. The next year, Cognasse et al reported also TLR2, TLR4, and TLR9 on platelets [115], and observed that expression levels increased two-fold upon platelet activation. More recently, the latter authors have followed up with further insights on platelet TLR's, and propose a major and unique role of platelets in bridging innate to adaptive immunity on this basis $[116,117]$. 
These findings add a new dimension to studies of TLR's in neuroinflammatory conditions. For example, the study by Chearwae and Bright of TLR4 and TLR9 in a model of MS documented upregulation of these receptors in $\mathrm{T}$ cells after induction of EAE, and favorable reduction along with amelioration of symptoms with prostaglandin and curcumin treatment [118]. However, now that platelets are known to also possess these receptors, it appears that their participation in such processes deserves consideration in future experiments of that kind.

\section{Peroxisome proliferator-activated receptors}

Peroxisome proliferator-activated receptors (PPAR's), of which three are known, are ligand-activated nuclear transcription factors of the hormone receptor superfamily. They are widely disseminated and appear to function chiefly in regulating metabolism, notably of fats, and this fact has elevated the fibrate drugs (agonists of PPAR) to a level of importance second only to the statins for prevention and treatment of coronary artery disease. However, like the statins, they seem to have "pleiotropic" effects, prominently including anti-inflammatory actions now under investigation for treatment of MS [119-121]. Indeed, the role of PPAR's in CNS disorders is of much current interest [122,123], with promise of applications in Parkinson's and Alzheimer's diseases among others [124,125]. Yang et al has reported on PPAR $\alpha$ regulation of immunity and the EAE model of MS [126]. PPAR's appear to be an important target of the NSAID's [127]. Interestingly, it appears that lysophophatidic acid (LPA) is a natural activator of PPAR [128], and that agonists of endocannabinoid receptors also stimulate PPAR in a model of MS [129]. Importantly for MS, PPAR appears to control inflammation induced by CD4+ T cell infiltration, at least in vitro [130].

Since platelets lack nuclei they are not expected to have PPAR's, but platelets are full of surprises. Both PPAR $\beta / \delta$ and PPAR $\gamma$ were found expressed in platelets [131]. Furthermore, the same authors have demonstrated that PPAR $\gamma$ is released from activated platelets on microparticles (PMP), which is taken up by promonocytic cell line in tissue culture; and that agonists of PPAR $\gamma$ induced platelet release as judged by secretion of sCD40L and thromboxane $\mathrm{A}_{2}\left(\mathrm{TxA}_{2}\right)$ [131]. Although the full implications of these late findings remains to be seen, they are paralleled by other developments in PPAR research, such as the recognition that active PPAR is not necessarily confined to the surface of the nucleus. The therapeutic potential of agonists of PPAR, such as rosiglitazone (Avandia ${ }^{\mathrm{TM}}$ ) and pioglitazone $\left(\operatorname{Actos}^{\mathrm{TM}}\right)$ for PPAR $\gamma$, needs further study but it has been shown that they inhibit platelet release of CD40L [131].

\section{Platelet-derived bioactive lipids}

Recognition that certain lipids perform critical signaling functions began in the 1970's with the observation that human semen caused contraction of uterine muscle strips, leading to identification of the prostaglandins, so called for that reason. Related families of active lipids, such as the leukotrienes and thromboxanes, subsequently came to light and are collectively known as the eicosanoids, for the 18-carbon arachidonic acid precursor in the cell membrane. From the outset, platelets were seen as a major source of these agents. Indeed, a common measure of platelet activation today is the circulating level of thromboxane $\mathrm{B}_{2}\left(\mathrm{TXB}_{2}\right)$, the stable breakdown product of thromboxane $\mathrm{A}_{2}$ (TXA $\mathrm{TA}_{2}$, half-life 30 sec's). That early work culminated in understanding the mechanism of aspirin and led to development of the other COX inhibitors and NSAID's, most of which inhibit platelet activation. Since that work is well-known, we shall limit discussion to brief review of some of the more interesting recent developments relevant to the link between platelets and neuro-inflammatory diseases. Several recent reviews are available on the general subject of bioactive lipids [132] and with emphasis on the neuronal nucleus [133].

\section{Lysophosphatidic acid (LPA) and sphingosisine-1- phosphate (S1P)}

The emerging significance of LPA in medicine has been reviewed [134,135] and with focus on autoimmune [136] and neurological diseases [137]. Its sphingolipid homo$\log , \mathrm{S} 1 \mathrm{P}$, will not be reviewed here because it is wellknown to neurologists as the target of FTY720 (fingolimod), a pro-drug that antagonizes the S1P receptor(s) to limit leukocyte migration for treatment of MS $[138,139]$.

LPA is formed mainly by the enzyme, autotaxin [a.k.a. lysophospholipase D (lysoPLD)], which is secreted by platelets and other cells and is inhibited by LPA $[140,141]$. Most authors accept platelets as the main source of plasma LPA, and this is supported by a study of the effect of aspirin in cerebral vascular disease: aspirin treatment reduced LPA levels, which rose again when aspirin was stopped, leading the authors to conclude that platelet activation is the major source of LPA [142]. LPA can also be formed by mild oxidation of low-density lipoprotein (LDL) [143]. Of the several known LPA receptors, LPA (5) is established for platelets, is highly selective, and may be centrally involved in platelet activation [144].

LPA alone appears to be a weak agonist of platelets but its potency is increased synergistically by the presence of other lysolipids [145]. Similarly, Eriksson et al found synergy of epinephrine with LPA in inducing 
adhesion of platelets to an albumin-coated surface [146]. The study of Kang et al [145] documents augmented production of CXCL16, a regulator of $\mathrm{T}$ cell migration, by macrophages due to presence of LPA (or S1P) following stimulation by LPS, of interest in MS because of parallels with S1P. Also of interest vis a vis MS is involvement of LPA in lymphocyte-endothelial interaction in high endothelial venules [147], and in endothelial barrier function [135]. It is reported that PPAR $\gamma$ is an important target of LPA [141], wherefore those authors are developing inhibitors of the LPA receptor. It has been convincingly shown that LPA is also involved in the regulation of blood pressure [148].

Lin et al showed that LPA stimulated expression of IL-8 and monocyte chemo-attractant protein-1 (MCP-1) in endothelial cells, in a manner that depended on IL-1 [149]. It is not widely appreciated that platelets are an important source of IL-1, particularly in a localized micro-environment [150]. Several studies have found potentially important links between platelet-derived LPA and cancer metastasis [151,152].

Interestingly, it has been found that human platelet responses to LPA depend strongly on individual donors [153], classified by those authors as "responders" and "non-responders", and leading them to propose a novel inhibitory pathway in the $\approx 20 \%$ of non-responsive subjects. Another group also reported variations in observed effects depending on donor [146]. In assembling this review we noted some apparent conflicts on the reported action of LPA on human platelets, which are probably resolved in part by donor differences. Indeed, it was reported that in mice, LPA markedly inhibited platelet activation, induced a bleeding diathesis, and attenuated thrombosis [140]. Such opposite effects may be explained by alternative receptors [154] but the details are obviously complicated and poorly understood. Much remains to be clarified about the role of LPA in hemostasis and thrombosis, and in its many other putative roles in health and disease.

\section{Endocannabinoids}

The endocannabinoids, such as 2-arachidonyl glycerol (2-AG), are lipid mediators discovered in 1995 which have recently shown promise against neuroinflammatory disorders, as in the virus EAE model of MS of Loria et al [155]. Mechanisms of this benefit are said to include activation of PPAR. With specific regard to platelets, a key enzyme involved was purified from platelets and studied [156], more recently in further detail [157]. There is no doubt that 2-AG can be produced by platelets, and that 2-AG induces platelet activation [158] but it is not yet clear if platelets possess one of the two receptors for $2-\mathrm{AG}$, dubbed $\mathrm{CB}(1)$ and $\mathrm{CB}(2)$, since those authors found no evidence for this receptor on platelets whereas Schafer et al found that a specific antagonist of $\mathrm{CB}(1)$, rimonabant, blocked the effect of 2AG [159].

\section{Lipoxins; resolvins, protectins}

These lipid mediators of inflammation are recently identified. The extent to which platelets contribute them has not (to our knowledge) been much studied but the fact that they are sensitive to aspirin [160] suggests platelets as a significant source, i.e., platelets are major players in the "inflammatory hypothesis" of cardiovascular disease [161]. The resolvins are named for their role in resolving inflammation. Being derived from omega-3 fatty acids via the lipoxygenase (LOX) pathway, this may offer a rational basis for the cardiovascular benefits of polyunsaturated fatty acids (PUFA's) [160,162,163]. Resolvins have been shown to inhibit reperfusion brain injury, and the brain lipid messenger, 10,17S-docosatriene, potently inhibited leukocyte infiltration and other negative measures [164]. Resolvin E1, derived from omega-3 eicosa fatty acid, inhibited platelets in an agonist-specific manner, reduced leukocyte rolling in venules of mice, and modulated expression of several adhesins in monocytes and neutrophils, possibly accounting for some of the benefits of dietary PUFA's [165]. Further work may lead to important new insights on lipid mediators in neurodegenerative diseases and their possible relationship to platelet activation [166-169].

\section{Platelet activating factor (PAF)}

PAF is named for its potent activation of platelets, with effects down to picomolar concentrations [170]. It was discovered in the late 1970's by its strong anaphylactoid action, distinct from that of complement C3a, C5a [171], and was found to be a potent chemotactic stimulus for inflammatory cells $[172,173]$. Its biochemistry was well described by Braquet [174], who also described some synthetic inhibitors of it intended as drug candidates, and the natural inhibitors from the plant, Gingko biloba, known as ginkgolides [175]. In vivo, PAF is rapidly broken down by a specific acetylhydrolase, PAFAH. Although not an eicosanoid, most PAF derives from the same enzyme system. Inhibitors of phospholipase A2, the rate-limiting step in the main route of PAF production, is under investigation as a drug target [176]. In EAE, elevated PAF in the spinal cord, which was not the result of reduced PAF-AH activity, appeared to be caused by cytosolic PLA2 activity [177]. For broader review of PAF as drug target, including for application to MS, see [178].

Evidence for PAF transport on platelet-derived microparticles (PMP) was reported [179], and more recently, the enzyme which degrades it, PAF-AH, was also identified on PMP [180]. PAF also circulates bound to plasma 
lipoproteins [181], is stabilized by albumin, and can be produced by many cells. Platelet activation induced by co-incubation with neutrophils stimulated by fMLP (fMLP stands for formyl-Met-Leu-Phe) was almost completely prevented by PAFR blockade; and the PAF released in the interaction was greater than the sum produced by platelets or neutrophils alone [182]. The explanation was that platelets secreted an inactive form of PAF (de-acetylated) which was re-acetylated by the neutrophils and then thrown back to strongly activate the platelets. This is consistent with our general hypothesis of the role of platelets in diseases such as MS: that platelets are active partners with leukocytes in their entry to the CNS. More specifically, the PAF secreted by the cooperation of platelets and leukocytes would facilitate opening the BBB in the microenvironment, since one of the most prominent actions of PAF is disruption of endothelial junctions [183-186].

Among the unexpected "pleiotropic" benefits of the statin drugs appears to be protection against neuronal damage caused by PAF [187]. It may be relevant that statin drugs have also been shown to inhibit release of endothelial microparticles [188], and this may apply also to platelet microparticles insofar as platelets have the same pathway of microparticle production.

A study of Japanese MS patients found that the PAF degrading enzyme, PAF-AH, was significantly lower in the patients [189] but this was not reflected in the genotype. On the other hand, the same group studied PAF receptor (PAFR) gene polymorphisms in MS and found significant differences compared to controls, concluding that this gene is a susceptibility factor for MS [190]. A gene microarray analysis of MS lesions revealed that transcripts for PAFR were among those elevated in chronic/silent plaques, as were the platelet-specific glycoproteins IIb and IIIa [191]. A few years later, Kihara et al reported that in an EAE model of MS, levels of mRNA for the PAF receptor (PAFR) in murine spinal fluid correlated with disease activity, and that knock-out of the PAFR gene resulted in lower incidence and abrogated severity of symptoms [192]. In earlier work, Callea et al reported 6-fold elevated PAF in the plasma of human RRMS patients and 15-fold elevation above controls in CSF [193]. Levels correlated with radiographic findings. The PAF subtype differed between plasma and CSF, indicating "different cellular origins" in the two compartments [193].

PAF can cause thrombocytopenia at levels as low as 3 $\mathrm{ng} / \mathrm{kg}$ [194]. Mild thrombocytopenia is sometimes reported for MS patients (see later) and is possibly a signature of PAF activity. A role for PAF in stroke and brain injury has long been suspected [195]. Blockade of PAFR substantially reduced leukocyte adhesion to endothelia of hamster cheek pouch vessels following ischemia and reperfusion [196].Osborn et al explored the protective action of plasma gelsolin on lipid mediators and found that it modestly but significantly $(\mathrm{p}<0.0001)$ inhibited LPA-induced platelet activation, but markedly inhibited PAF-induced platelet activation ( $>75 \%$ inhibition) at physiological gelsolin concentrations [197]. Thus, gelsolin may be an important natural modulator of PAF activity; plasma gelsolin is often reduced in association with disease [197].

\section{Others}

This review provides only a sampler of agents of interest in each category. Several other classes of lipid mediators relevant to platelets in neuroinflammation are covered in the reviews cited earlier, e.g. the several phosphatidyl inositol phosphates (PIP's), sphingosines, and the recent discovery of the importance of palmitoylation. Of closely related interest are the many phospholipases whose activities govern most lipid mediators.

\section{Inflammatory agents of the coagulation system}

In the last decade it has come to attention that several of the coagulation proteins are inflammatory or antiinflammatory, and these are relevant to neurodegenerative diseases because they are implicated in MS (see later). They relate to platelets since the two systems go hand-in-hand: Activated coagulation stimulates platelets (e.g., thrombin) and activated platelets amplify coagulation.

\section{Fibrinogen}

The emergence of fibrinogen as a potent neuroinflammatory mediator has been a surprise [198,199]. It has been identified in lesions of MS patients, as referenced in following sections.

\section{The protein C system}

The protein $C$ system acts to curtail thrombin generation, mainly by inactivation of activated FV, but is rather complicated owing to cofactors such as protein S, protein $\mathrm{C}$ inhibitor, thrombomodulin, the endothelial protein $C$ receptor (EPCR), and other complexities [200]. Protein $\mathrm{C}$ itself is a vitamin $\mathrm{K}$-dependent PL-binding protein, meaning that it can exert its function on activated platelets, but also on the endothelium via EPCR. Perhaps the most spectacular demonstration of its antiinflammatory potential was the discovery that activated protein $\mathrm{C}(\mathrm{aPC})$ is an effective therapy for sepsis, regarded as a severe inflammatory state [201,202]. This is remarkable in view of the decades of failed efforts to treat sepsis. The anti-inflammatory efficacy of aPC appears to be largely independent of its anti-coagulant action. The use of aPC in MS has been little investigated, but proteomic analysis of MS lesions revealed protein C inhibitor [203], leading those authors to demonstrate substantial benefits of aPC in the EAE 
model of MS. Genc had previously made a good case for such investigations, citing relevant literature [204]. Thrombomodulin was also effective in an animal model of inflammation induced by lipopolysaccharide (LPS) [205].

\section{Contact proteins}

The kinin-kininogen system (KKS) is most familiar for instigating the contact (or intrinsic) coagulation cascade [206] and participating in platelet aggregation [207]. Its components are known inflammatory mediators [208]. Of direct relevance to MS, it was recently shown that a kinin receptor is pivotal to $\mathrm{T}$ leukocyte recruitment to the CNS [209]. The KKS system overlaps somewhat with the complement system. According to Colman, a specialist in the KKS system [210], it came to light through investigations of snake bites, leading to the discovery of the vasoactive nonapeptide, bradykinin, released by cleavage of high-molecular weight kininogen (HMWK, a.k.a. HK). Bradykinin is a main target of the widely prescribed ACE inhibitors, which are proving to have unexpected neuroprotective effects, i.e. independent of blood pressure [211]. With regard to the role of platelets in the above-cited study [209], it has been shown that platelet-leukocyte interaction can occur via HMWK bridging from platelet GP $1 \mathrm{~b} \alpha$ to the CD11b/ CD18 complex (Mac-1) on leukocytes [212]. The more conventional mode of interaction is between P-selectin of platelets and P-selectin glycoprotein ligand-1 (PSGL1, CD162) on leukocytes, which can be effectively blocked by antibodies to the sialyl Lewis ${ }^{\mathrm{x}}$ antigen [43]. Interestingly, PSGL-1 was recently reported to be the means of entry of the neurotropic enterovirus 71 , and probably other neuropathic viruses of the same family [213], but those authors do not offer insight on how it then gains access to the CNS. In view of the foregoing, a possible role for platelets warrants consideration.

\section{Thrombin}

Lastly, thrombin itself has long been recognized for its inflammatory actions, recently extended by the finding that it is required to initiate CCR2-dependent leukocyte recruitment, and that it is "the principal determinant of the outcome after vascular injury" in several animal models (LPS-induced endotoxemia, antibody-mediated graft rejection, carotid artery ligation) [214].

\section{Platelets and complement}

The complement (C) system is a humoral arm of the innate immune system and can attack self-cells when marked by autoantibodies or due to defects in proteins that protect against C. It is a complicated system of circulating proteins, analogous to the coagulation system in that its activation involves a series or cascade of proteolytic conversions of zymogens to their active forms, resulting in several ultimate products, notably, the C5b-9 membrane attack complex which kills by punching holes in the target cell. The $\mathrm{C}$ system has several links to the coagulation system $[215,216]$. For example, protein $S$, a cofactor of the protein $C$ system, is carried in circulation largely bound to $\mathrm{C} 4$ binding protein (C4bp), a complement component. It is well known that $\mathrm{C}$ is central to the pathology of many autoimmune and inflammatory disorders.

Platelets possess $\mathrm{C}$ receptors CR2, CR3, CR4, C1q, C1inhibitor, and factors $\mathrm{D}$, and $\mathrm{H}$. Others are listed in some sources but are disputed as they may be acquired from plasma. Platelets are capable of deploying the lethal C5b-9 complex [217]. In addition, like other blood cells, platelets contain a set of membrane proteins which specifically protect them against autologous Cmediated attack, i.e. against self-injury by $C$ [218]. These are CD55 (decay accelerating factor, DAF), CD59 (membrane inhibitor of reactive lysis, MIRL), and homologous restriction factor (HRF) $[219,220]$. Morgan mentions others less well defined. Recently, another such protective protein, Crry, was identified in murine platelets and erythrocytes $[221,222]$, later extended by those authors to work on leukocytes [223], but Crry appears to be absent in humans. Defects in these proteins can result in pathology, e.g. paroxysmal nocturnal hemoglobinuria (PNH). We investigated CD59 on platelets from PNH patients and found levels $\approx 10 \%$ of normal, but findings on altered sensitivity to $\mathrm{C}$-mediated lysis were inconclusive [224].

A recent finding of significance in neurology is that platelet-bound complement fragment, C4d, is a highly specific biomarker for systemic lupus erythematosus (SLE) and neuropsychiatric lupus [225]. Those authors propose this as a biomarker of cerebrovascular inflammation generally. Moreover, it correlated closely with positive lupus anticoagulant (LA) $(\mathrm{p}<0.0001)$, and less well with positive anti-cardiolipin $(\mathrm{aCL})(\mathrm{p}=0.035)$ [225]. Work by the same authors demonstrated that platelet-bound C4d was associated with ischemic stroke [226]. We have drawn attention to evidence for Cmediated injury in the neuropsychiatric aspect of antiphospholipid syndrome, which can resemble MS, as referenced [66]. According to Roach et al, C5a signaling in macrophages is synergistic with PAF and with LPA [227].

Despite the presence of the above mentioned protective proteins, platelets are very sensitive to $\mathrm{C}$-mediated attack. We have witnessed the serum-dependent fragmentation of platelets into microparticles when opsonized with an anti-platelet IgM [228]. However, platelets are not entirely defenseless against $\mathrm{C}$, as it has been shown that attack complexes are selectively shed from 
the platelet membrane on platelet microparticles (PMP), allowing recovery of the parent cell $[229,230]$. Butikofer et al has shown that the microparticles released from erythrocytes are selectively enriched in proteins that protect against autologous $\mathrm{C}$, at the expense of these proteins in the parent cell, and in their discussion cite evidence that same is true of platelets [231]. This implies that microparticle shedding sensitizes the remnant cell to $\mathrm{C}$-mediated injury.

\section{New methods are expanding the inventory of platelet constituents}

The list of active agents in platelets has been expanding in recent years by application of new technologies: proteomics, lipidomics, and mRNA transcript analysis. Hundreds of proteins were identified - and many others were not identified - in the supernatant of activated platelets [232-234]. Some 578 proteins were identified just in platelet microparticles [235]. Several proteomic studies of the whole platelet membrane were recently reviewed [236], with a special section devoted to proteins of the lipid rafts. (Lipid rafts are regions of the membrane which resist detergent solubilization and play critical roles in platelet physiology [237,238]). Raft regions are selectively shed with microparticles, e.g. [239].

The platelet "transcriptome" is also growing. Although platelets lack nuclei, thousands of transcripts have been identified in platelets, including coding for enzymes, interleukin receptors, etc., many of which were previously unknown in platelets, e.g. PEAR-1 [240-242]. Some of the same leaders in the field have sought to extend proteomic studies to include platelet-specific genes [243]. A recent paper claims to show that nuclear factor NFkB is not only present in platelet but active [244], which seems impossible since NFkB is a nuclear transcription factor, as discussed in an editorial [245]. The still-nascent field of lipidomics, which applies the same methods as proteomics (mass spectrometry) but to lipids, promises great advances in sorting out the myriad of bioactive lipids. Potentially important new platelet proteins continue to come to light, such as the septins, reviewed in relation to neurodegenerative disorders [246], and the vanilloid receptor (TRPV1) for noxious stimuli such as capsaicin [247] but also for several catechol amine metabolites such as homovanillic acid [248]. We shall cite the significance of some of this work to MS presently.

\section{Serotonin: a platelet-neuron nexus?}

In 1985, Stahl pointed out a number of parallels between platelets and neurons, with focus on the storage and secretion of serotonin (5-HT), and the similar sensitivities to many CNS-active drugs [249]. Reed et al devoted a section of their review of mechanisms of platelet secretion to a comparison with vesicle trafficking in neurons [250], echoing work by Lemons et al [251]. Steidl et al in a study of CD34+ hematopoietic progenitor cells identified numerous ion channels, neuromediators, and other proteins previously assumed to be restricted to the CNS [252]. The reason for abundant acetylcholinesterase activity of erythrocytes (but not platelets [253]) remains a mystery attracting much interest [254-257]. The above-mentioned finding of endocannabinoid receptors, semaphorin $\mathrm{A}$, monoamine oxidase (MAO), etc., on platelets is more of the same.

Serotonin (5HT) does not itself cross the BBB but some of its metabolites or precursors do, resulting in a degree of correlation between peripheral and CNS levels of $5 \mathrm{HT}$ [258]. Platelets are the main source of circulating $5 \mathrm{HT}$ but arteries and veins can act as reservoirs [259]. Of the several receptors for $5 \mathrm{HT}$, platelets possess $5 \mathrm{HT}(1)$, as well as a serotonin transporter (SERT). Among the more surprising recent discoveries is the role of $5 \mathrm{HT}$ in regulating bone density [260].

Of direct relevance to inflammation is the demonstration that 5HT enhanced monocyte stimulation of CD4+ $\mathrm{T}$ cells and cytokine production following LPS exposure [261]. That paper also reports increased plasma 5HT in Alzheimer's disease (AlzD), which correlated with disability index [261]. Ciz et al reported inhibition of the oxidative burst of phagocytes by $5 \mathrm{HT}$, via action on the 5HT receptor and on myeloperoxidase activity [262].

Treatment of MS with selective serotonin reuptake inhibitors (SSRI's) was reportedly very promising [263]. Plasma levels of $5 \mathrm{HT}$ are governed mainly by the number of SERT's on the platelet, with more or less of them appearing at the membrane surface depending on external 5HT concentration [264]. Accordingly, the number of SERT's per platelet is sensitive to SSRI's. Platelet SERT density correlated closely with P-selectin expression, a marker of platelet activation and cell-cell interaction, consistent with the concept of $5 \mathrm{HT}$ as a weak agonist [265]. However, Galan et al concluded that, contrary to tradition, $5 \mathrm{HT}$ is not a weak agonist of platelets, but instead sensitizes them or potentiates their responsiveness [266].

Abdellah et al observed significant differences in the action of SSRI on platelets, depending on polymorphisms of the gene for SERT (SLC6A4) and its promoter (5-HTTLPR) [267]. In an EAE model, it was found that knock-out of SERT caused increased plasma $5 \mathrm{HT}$ and attenuated symptoms, with effects most pronounced in female animals [268]. Interestingly, a strong gender effect was seen also with the influence of cannabinoids (in habitual cannabis smokers with cognitive impairment) on 5HT uptake in plasma [269]. In MS, levels of $5 \mathrm{HT}$ in CSF appear to correlate well with progression of 
disease [270]. Norepinephrine, at plasma levels seen in stress disorders, desensitizes the $5 \mathrm{HT}(1)$ receptor by uncoupling it from SERT via G proteins, leading the authors to conclude that NE can modulate $5 \mathrm{HT}$ responses and the action of SSRI's [271].

It was recently shown that $5 \mathrm{HT}$ can become covalently bound to a number of proteins, a process termed seritonylation, including to small GTPase's, with roles at the vessel wall [272] and in platelet activation [273]. The latter authors report that low levels of plasma $5 \mathrm{HT}$ markedly prolong the bleeding time. In summary, these brief notes from a large literature suggest that $5 \mathrm{HT}$ from platelets, or acting on platelets, may be a significant factor in neuroinflammatory conditions, especially in a restricted microenvironment such as at the BBB.

\section{Platelets and Alzheimer's disease: untangling the tangles}

Although the focus of this review has been on MS, many of the papers cited refer also to other neuroinflammatory disorders. Here we take the example of Alzheimer's disease (AlzD). In 1998, we reported chronic platelet activation in AlzD [274] but that work was largely ignored in the blinding light of the $\beta$-amyloid hypothesis. Several recent developments are now forcing a "radical rethink" of the disease. (i) Platelet activation in AlzD has been confirmed [275]. Levels of homocysteine, considered a marker of hypercoagulable state, also impact on AlzD [276]. (ii) Two recent large genetic studies uncovered, in addition to APOE, three other AlzD-related genes, notably clusterin and CR1, both signatures of complement involvement [277,278]. (iii) Mounting evidence indicates that AlzD is inflammatory in nature and etiology [279], and that it can be controlled by exercise [280] and possibly diet [281]. (iv) Consistent with an inflammatory vascular etiology is the presence of complement fragment $\mathrm{C} 1 \mathrm{q}$ in the brain lesions of a mouse model [282] and of the coagulation protein, fibrinogen, in human AlzD plaque [283]. (v) The hypothesis that agerelated cognitive decline generally is mainly a vascular condition is supported by finding that retinal microvascular abnormalities predict decline [284]. (vi) To the extent that $\beta$-amyloid is truly causative, it should be noted that platelets are the principal source of amyloid precursor protein (APP) $[285,286]$. However, the relation of plasma levels of $\beta$-amyloid forms to AlzD has been controversial, and ratios of some of the forms are associated as much with vascular dementia as with AlzD [287]. In this connection, it is relevant to note that platelets appear to be responsible for post-surgical cognitive impairment [288].

Finally, (vii) recent work linking all of the above into one coherent hypothesis was brought to our attention during peer review of this paper: Platelets are now strongly implicated in the overexpression of the enzyme which liberates the offending peptide, amyloid- $\beta$ (A $\beta)$, from APP, known as BACE ( $\beta$-site APP Cleaving Enzyme), or generically, " $\beta$-secretase". BACE was first identified as the long-sought $\beta$-secretase in 1999 [289] but those authors did not assay platelets in their study of its tissue distribution. In 2004, a direct relation was found between early-stage AlzD and platelet activity of BACE, as well as ADAM10, leading those authors to propose this assay as a diagnostic aid [290]. (ADAM10, also on platelets, has similar activity [291]). This was confirmed in 2005 [292] and again in 2008 [293]. BACE inhibitors to protect against progression of AlzD are in active development, but $\mathrm{Hu}$ et al advise caution because of their finding that BACE inhibition also delays (but does not totally abolish) remyelination by blocking cleavage of neuroregulins [294]. Interestingly, it was recently shown that platelet membrane cholesterol content modulates the activity of $\beta$-secretase, possibly explaining reported relations between cholesterol, dietary lipids, and AlzD [295].

\section{Platelets in multiple sclerosis: smoking gun?}

MS is an immune-mediated demyelinating disease of the CNS and can be regarded as a model neuroinflammatory condition. Like most other autoimmune disorders, the etiology and pathophysiology of MS remains uncertain but most agree that a combination of genetic and environmental factors are required to initiate an immune reaction against $\mathrm{CNS}$ antigens. For example, Gong et al [296] has proposed a 5HT deficiency at high latitudes as a predisposing factor in the epidemiology.

The possible involvement of platelets in MS was first studied by Putnam in 1935, who considered a role for venule thrombosis in CNS demyelination [297]. In the 1950's-60's, at least ten studies appeared on the relation of platelets to CNS demyelination, several of which reported augmented platelet adhesiveness in MS, which correlated with disease activity [298-301]. More recently, a number of observations of platelet abnormalities in MS patients have appeared [302-304], and others cited below. We became interested when colleague W. Sheremata encountered MS patients with severe immune thrombocytopenic purpura (ITP) [305], leading to our report of increased platelet microparticles and platelet activation marker CD62P (P-Selectin) in MS [306]. Thus, chronic platelet activation in MS may now be regarded as well established, including by the report of Cananzi et al cited earlier [54]. Epidemiological studies have found a prevalence of ITP-like thrombocytopenia in MS patients about 25-fold higher than in the general population [304,307]. As earlier mentioned, mild thrombocytopenia, which could often be overlooked as insignificant, could be a signature of PAF activity.

It may be objected that a modest degree of platelet activation in MS is simply a consequence of general 
inflammation. However, the finding of platelet-specific GP IIb/IIIa in lesions of MS patients [191] comes close to "Smoking-Gun" evidence of platelet involvement. Relatedly, several elements of coagulation have been detected in the lesions including fibrin, tissue factor (TF), and protein C, suggestive of a procoagulant state [191,203].

For these and other reasons, MS has been described as a vascular disease [308]. The adhesion molecule, PECAM-1, may be particularly important in this regard. It was reported in 1999 that levels of serum soluble PECAM-1 (sPECAM-1) are significantly elevated in patients with active, gadolinium-enhancing lesions [309]. In 2001, we reported that PECAM-1-positive endothelial microparticles (EMP) are elevated in MS patients only during relapses, and correlated well with gadoliniumenhancing lesions [310]. In 2005, another study documented increased sPECAM-1 during acute relapse and in remission compared with progression [311]. It is not clear if the microparticle-bound form is functionally distinct from the soluble form but we have discussed examples of "soluble" biomarkers which are in fact membrane particle-bound [52] (Part D). These and other findings suggest that PECAM-1, whether soluble or MP-bound, may be at least an indicator of BBB disruption in MS and a biomarker of disease activity, and probably a key participant. The PECAM-1 gene is located on chromosome 17 in the region $17 q 23$ [312] and, given that the region $17 \mathrm{q} 22$ was proposed to be an MS-susceptibility factor, PECAM-1 seemed to be a good candidate gene. However, at least two studies failed to find convincing support for that hypothesis [313,314].

Our findings, together with evidence reviewed in prior sections, suggest a broader hypothesis, namely, that platelet interaction with leukocytes at the endothelium of the $\mathrm{BBB}$ is responsible for the release of PECAM-1 to the circulation, and associated infiltration of leukocytes. Platelets are capable of directly activating both lymphocytes and dendritic cells $[103,315]$. In addition, it is tempting to postulate involvement of platelet activating factor (PAF) in view of its potency at disrupting endothelial junctions, and likely signature of thrombocytopenia (see Section 9). Elevation of PAF in the CSF and plasma of RRMS patients was reported, and the authors concluded that PAF is likely responsible for the early disruption of the BBB in MS [193]. Moreover, PAF receptors are up-regulated in MS lesions [191].

Differences in these parameters between RRMS and progressive MS have been noted in several reports, hinting at distinctive pathophysiologic pathways. Humm et al observed such differences in responses to prednisone [316]; and PAF activity was higher in RRMS than in secondary progressive MS [193]; and stronger differences were observed in sP-Selectin and other markers in RRMS compared to secondary progressive [311].
As earlier mentioned (Section 9), PAF is inactivated by PAF-AH but no association of the inactivating mutation of the PAF-AH gene with RRMS or progressive MS was found [189]. Nevertheless, the PAF-AH activities in MS were significantly lower than in healthy controls [189]. Such a decrease of PAF-AH activity may in part be responsible for the reported increase of PAF in MS plasma and CSF, and therefore could contribute to the inflammation and vascular permeability changes seen in the CNS of MS. On the other hand, a small Japanese study did find a significant association between MS susceptibility and a PAFR polymorphism causing a modest but significant reduction of PAF-dependent signaling [190].

We also found that platelet-associated IgM (but not IgG) is increased in MS patients [317]. We feel that this is of potential importance to understanding the pathophysiology of MS. However, present knowledge of antiphospholipid antibodies is too fragmentary to offer much insight on the significance of this finding, as discussed [66].

In summary, there are numerous mechanisms by which platelets could substantially contribute to the pathophysiology of MS. We do not pretend to have any specific hypothesis, nor do we propose that some bizarre platelet abnormality actually causes MS (although that is not impossible). Rather, the purpose of this review is to call attention to the neglected platelet and its potential to modulate inflammatory processes.

\section{Summary and conclusions}

This review indicates that platelets could be pivotally involved with neurodegenerative and autoimmune conditions. At present, the potential role of platelets in such disorders has been neglected, although well appreciated in the cardiovascular and cancer research fields. The majority of studies in tissue culture designed to elucidate the pathophysiology of neurodegenerative diseases such as MS have investigated interactions of leukocyte subsets and endothelial cells, but it is likely that these interactions could be significantly modulated in the presence of platelets from patients $v s$. healthy controls.

The question may arise, exactly what kind of hypothesis could link platelets to such a wide variety of neurological conditions? Our view is that platelets are partners with leukocytes and other immunological effectors (complement, TLR's, PPAR's, resolvins, PAF, CD40/ CD40L, etc.), amplifying or otherwise modulating those effectors in ways distinctive for each condition, with actions likely to be most prominent at the BBB.

A number of topics and many references were cut from this review because of excessive length. They include the role of platelets in several viral infections, consideration of other possibly relevant receptors (e.g., 
vanilloids, vasopressin), new work dissecting prothrombotic from inflammatory pathways, and further details on the topics covered. However, it is hoped that enough has been said to inspire new respect for the humble little platelet.

If this review succeeds in raising awareness of the potential roles of platelets in neurodegenerative and neuroinflammatory conditions, the labor of assembling it will have been amply rewarded.

\section{Author details}

'Wallace Coulter Platelet Laboratory, Division of Hematology and Oncology, Department of Medicine, Miller School of Medicine, University of Miami, Miami, Florida, USA. ${ }^{2}$ Buffalo Neuroimaging Analysis Center, The Jacobs Neurological Institute, Department of Neurology, School of Medicine and Biomedical Sciences, State University of New York at Buffalo, Buffalo NY, USA. ${ }^{3}$ Department of Neurology, Isfahan University of Medical Sciences, Isfahan, Iran. ${ }^{4}$ Department of Cellular and Molecular Physiology, Louisiana State University Health Sciences Center, Shreveport, LA 71130, USA. ${ }^{5}$ Department of Neurology, Louisiana State University Health Sciences Center, Shreveport, LA 71130, USA.

\section{Authors' contributions}

LLH, WJ, YSA, AHM, RZ, ME, JSA, and AM performed extensive literature research, prepared the manuscript and provided expertise in interpretation of data obtained from several sources.

AHM and ME wrote the section on platelets and multiple sclerosis.

JSA and AM reviewed the manuscript extensively and provided constructive comments to improve the quality of the manuscript.

LLH, WJ, YSA, RZ, and AM provided clinical expertise in various fields of neuroinflammation and improved the quality of the original manuscript. All authors worked as team members to generate this extensive review. All authors read and approved the final manuscript.

\section{Competing interests}

The authors declare that they have no competing interests.

Received: 4 November 2009

Accepted: 3 February 2010 Published: 3 February 2010

\section{References}

1. McNicol A, Israels SJ: Beyond hemostasis: the role of platelets in inflammation, malignancy and infection. Cardiovasc Hematol Disord Drug Targets 2008, 8:99-117.

2. Martin JF, Levine RP: Evidence in favor of the lungs and against the bone marrow as the site of platelet production. The Platelet in Health and Disease London Blackwell ScientificPage CP 1991

3. Aarts PA, vandenBroek SA, Prins GW, Kuiken GD, Sixma JJ, Heethaar RM: Blood platelets are concentrated near the wall and red cells in the center in flowing blood. Arteriosclerosis 1985, 8:819-24.

4. Jy W, Jimenez JJ, Horstman LL, Ahn YS: Platelets, coagulation and thrombosis. Ch. 8. Interventional Cardiology Secrets NY London Elsevier PressMarchena Ed, Ferrara A 2003, 42-50.

5. Gresele P, Falcinelli E, Momi S: Potentiation and priming of platelet activation: a potential target for antiplatelet therapy. Trends Pharm Sci 2008, 29:352-60.

6. Zwaal RFA, Schroit AJ: Pathophysiologic implications of membrane phospholipid asymmetry in blood cells. Blood 1997, 89:1121-32.

7. Bick RL: Hematology: Clinical and Laboratory Practice [2 volumes]. St Louis MO Mosby 1993.

8. Hoffman R, Benz EJ, Shattil SJ, Furie B, Cohen HJ, Silberstein LE, McGlave P: Hematology: Basic Principles and Practice [4th Ed'n; portions updated 2005]. Philadelphia: Elsevier, Churchill, Livingstone 2005.

9. Handin RL, Lux SE, Stossel TP: Blood: Principles and Practice of Hematology [2nd Ed'n]. Philadelphia: Lippincott, Williams and Wilkins 2003.
10. Colman RW, Hirsh J, Marder VJ, Salzman EW: Hemostasis and Thrombosis [3rd Ed'n]. Philadelphia, PA: J B Lippincott Co 1994.

11. Gresele P, Page CP, Fuster V, Vermylen J: Platelets in thrombotic and nonthrombotic disorders: Pathophysiology, pharmacology and therapeutics. Cambridge, UK: Cambridge University Press 2002.

12. Clawson CC: Platelets in bacterial infections. Immunopharmacology of Platelets London/New York: Academic PressJoseph M 1995, 83-124.

13. Joseph M: The generation of free radicals by blood platelets (Ch. 11). Immunopharmacology of Platelets London/New York: Academic PressJoseph M 1995, 209-23

14. Herd CM, Page CP: Do platelets have a role as inflammatory cells? (Ch. 2). Immunopharmacology of Platelets London/New York: Academic PressJoseph M 1995, 1-12.

15. McGregor $\mathrm{JL}$ : The role of human platelet membrane receptors in inflammation [Ch 4; see also Ch. 2]. Immunopharmacology of Platelets London/New York: Academic PressJoseph M 1995, 66-82.

16. Weyrich AS, Lindemann S, Zimmerman CA: The evolving role of platelets in inflammation (Review). J Thromb Haemost 2003, 1:1897-905.

17. Tang BL: ADAMTS: a novel family of extracellular matrix proteases. Internat J Biochem Cell Biol 2001, 33:33-44.

18. Nagase H, Visse R, Murphy G: Structure and function of matrix metalloproteinases and TIMPs [Theme Issue on MMP]. Cardiovasc Res 2006, 69:562-73

19. Waubant E: Biomarkers indicitive of blood-brain barrier disruption in multiple sclerosis. Dis Markers 2006, 22:235-44.

20. Yong WW, Power C, Forsyth P, Edwards DR: Metalloproteinases in biology and pathology of the nervous system. Nat Rev Neurosci 2001, 2:502-13.

21. Graesser D, Mahooti S, Haas T, Davis S, Clark RB, Madri JA: The interrelationship of alpha-4 integrin and matrix metalloproteinase-2 in the pathogenesis of experimental autoimmune encephalomyelitis. Lab Invest 1998, 78:1445-8.

22. Leppert D, Raija L, Lindberg P, Kappos L, Leib SL: Matrix metalloproteinases: Multifunctional effectors of inflammation in multiple sclerosis and bacterial meningitis. Brain Res Rev 2001, 36:249-57.

23. Yong WW, Zabad RK, Agrawal S, Dasilva AG, Metz LM: Elevation of matrix metalloproteinases (MMPs) in multiple sclerosis and impact of immunomodulation. J Neurol Sci 2007, 259:79-84.

24. Alldinger $\mathrm{S}$, Groters $\mathrm{S}$, Miao Q, Fonfara S, Kremmer E, Baumgartner W: Roles of extracellular matrix (ECM) receptor and ECM processing enzymes in dymelinating canine distemper encephalitis. DTschTieraxti Wochenschr 2006, 113:151-6.

25. Sporer B, Koedel U, Paul R, Ertle V, Fontana A, Pfister HW: Human immunodeficiency virus type-1 Nef protein induces blood-brain barier disruption in the rat: role of matrix metalloproteinase-9. J Neuroimmunol 2000, 102:125-30.

26. Amantea D, Nappi G, Bernardi G, Bagetta G, Corasaniti MT: Post-ischemic brain damage: pathophysiology and role of inflammatory mediators. FEBS J 2009, 276:13-26

27. Ram M, Sherer T, Shoenfeld Y: Matrix metalloproteinase-9 in autoimmune diseases. J Clin Immunol 2006, 26:299-307.

28. Prince HE: Biomarkers for diagnosing and monitoring autoimmune diseases. Biomarkers 2005, 10(sup1):S44-S9.

29. Muraski ME, Roycik MD, Newcomer RG, VanDenSteen PE, Opdenakker G, Monroe HR, Sahab ZJ, Sang QX: Matrix metalloproteinase-9/gelatinase B is a putative therapeutic target of chronic obstructive pulmonarty disease and multiple sclerosis. Curr Pharm Biotech 2009, 9:4-46.

30. Minagar A, Alexander JS, Schwendimann RN, Kelley RE, Gonzalez-Toledo E, Jimenez JJ, Mauro L, Jy W, Smith SJ: Combination therapy with interferon beta-1a and doxycycline in multiple sclerosis: an open-label trial. Arch Neurol 2008, 65:199-204.

31. Kim HS, Suh YH: Minocycline and neurodegenerative diseases. Behav Brain Res 2009, 196:168-79.

32. Yong WW, Giuliani F, Xue M, Bar-Or A, Metz LM: Experimental models of neuroprotection relevant to multiple sclerosis. Neuropathology 2007, 68(22 Sup3):S32-57.

33. Clerico M, Contessa G, Durelli L: Interferon-beta 1a for the treatment of multiple sclerosis. Expert Opin Biol Ther 2007, 7:535-42.

34. Markowitz CE: Interferon-beta: mechanism of action and dosing issues. Neurology 2007, 68(24 sup4):S8-S11. 
35. Yong WW, Agrawal SM, Stirling DP: Targeting MMPs in acute and chronic neurological conditions. Neurotherapeutics 2007, 4:580-9.

36. Gasche Y, Soccal PM, Kanemitsu M, Copin JC: Matrix metalloproteinases and diseases of the central nervous system with a special emphasis on ischemic brain. Front Biosci 2006, 11:1289-301.

37. Agrawal SM, Lau L, Yong WW: MMPs in the central nervous system: where the good guys go bad. Semin Cell Dev Biol 2008, 19:42-51.

38. Santos-Martinez MJ, Medina C, Jurasz P, Radomski MW: Role of metalloproteinases in platelet function. Thromb Res 2008, 121:535-42.

39. Jy W, Lin A, Bidot L, Bang J, Ahn E, Horstman LL, Jimenez JJ, Bidot CJ, Ahn YS: A significant fraction of ADAMTS13 activity is associated with activated platelets and their microparticles (PMP): implication for regulating ADAMTS13 activity. Blood 2006, 108(11):317a.

40. Kim YS, Joh TH: Microglia, major player in the brain inflammation: their roles in the pathogenesis of Parkinson's disease. Exp Mol Med 2006, 38:333-47.

41. Rinder HM, Bonan JL, Rinder CS, Ault KA, Smith BR: Dynamics of leukocyteplatelet adhesion in whole blood. Blood 1991, 78:1730-7.

42. Rinder HM, Bonan JL, Rinder CS, Ault RA, Smith BR: Activated and unactivated platelet adhesion to monocytes and neutrophils. Blood 1991, 78:1760-9

43. Jy W, Mao WW, Horstman LL, Tao J, Ahn YS: Platelet microparticles bind, activate and aggregate neutrophils in vitro [with color photomicrographs]. BCMD (Blood Cells, Molecules and Diseases) 1995, 21:217-31.

44. Ruef J, Kuehni P, Meinertz T, Merten M: The complement factor properdin induces formation of platelet-leukocyte aggregates via leukocyte activation. Platelets 2008, 19:359-64.

45. Izzi B, Pampuch A, Constanzo S, Vanhout B, lacoviello L, Cerietti C, deGaetano G: Determination of platelet conjugate formation with polymorphonuclear leukocytes in whole blood. Thromb Haemost 2007, 98:1276-84.

46. Hilberg T, Menzel K, Glaser D, Zimmermann S, Gabriel HH: Exercise intensity: platelet function and platelet-leukocyte conjugate formation in untrained subjects. Thromb Res 2008, 122:77-84

47. Soriano AO, Jy W, Chirinos JA, Valdivia MA, Velasquez HS, Jimenez JJ, Horstman LL, Kett DH, Schein RMH, Ahn YS: Levels of endothelial and platelet microparticles and their interactions with leukocytes correlate with organ dysfunction and predict mortality in severe sepsis. Crit Care Med 2005, 33:2540-6

48. Chung AW, Radomski A, Alonso-Escolano D, Jurasz P, Stewart MW, Malinsky T, Radomski MW: Platelet-leukocyte aggregation induced by PAR agonists: regulation by nitric oxide and matrix metalloproteinass. $\mathrm{Br} J$ Pharmacol 2004, 143:845-55.

49. Janowska-Wieczorek A, Marquez-Curtis L, Wieczorek M, Ratajczak MZ: Enhancing effect of platelet-derived microvesicles on the invasive potetial of breast cancercells. Transfusion 2005, 46:1199-209.

50. Dashevsky O, Varon D, Brill A: Platelet-derived microparticles promote invasiveness of prostate cancer cells with upregulation of MMP-2 production. Int J Cancer 2009, 14:1773-7.

51. Janowska-Wieczorek A, Wieczorek M, Kijowski J, Marquez-Curtis L, Michalinski B, Ratajczak J, Ratajczak MZ: Microparticles derived from activated platelets induce metastasis and angiogenesis in lung cancer. Int J Cancer 2005, 113:752-60

52. Horstman LL, Minagar A, Jy W, Bidot CJ, Jimenez JJ, Ahn YS: Cell-derived microparticles and exosomes in neuroinflammatory conditions [Review]. Int Rev Neurobiol 2007, 79:229-68.

53. Horstman LL, Jy W, Bidot C, Nordberg ML, Minagar A, Alexander JS, Kelley RE, Ahn YS: Possible roles of cell-derived microparticls in ischemic brain disease. Neurol Res 2009, 31:799-806.

54. Cananzi AR, Ferro-Milone F, Grigoletto F, Toldo M, Meneghin F, Brotoloni F, D'Andrea G: Relevance of platelet factor 4 (PF4) plasma levels in multiple sclerosis. Acta Neurol Scand 1987, 76(2):79-85.

55. Ludwig A, Weber C: Transmembrane chemokines: Versatile 'special agents' in vascular biology. Thromb Haemost 2007, 91:694-703.

56. Power CA, Clemetson JM, Clemetson KJ, Wells TN: Chemokine and chemokine receptor mRNA expression in human platelets. Cytokine 1995, 7(6):479-82.

57. Power CA, Furness RB, Brawand C, Wells TN: Cloning and full-length CDNA encoding the neutrophil-activating peptide ENA-78 from human platelets. Gene 1994, 151:333-334
58. Power CA, Meyer A, Nemeth K, Bacon KB, Hoogewerf AJ, Proudfoot AE, Wells TN: Molecular cloning and functional expression of a novel CC chemokine receptor CDNA from a human basophilic cell line. J Bio Chem 1995, 270:19495-500.

59. Wang JF, Liu ZY, Groopman JE: The alpha-chemokine receptor CXCR4 is expressed on the megakaryocytic lineage from progenitor to platelets and modulated migration and adhesion. Blood 1998, 92:756-64.

60. Clemetson KJ, Clemetson JM, Proudfoot AEI, Power CA, Baggiolini M, Wells TNC: Functional expression of CCR1, CCR3, CCR4, and CXCR4 chemokine receptors on human platelets. Blood 2000, 96:4046-54.

61. Sheng GY, Huang XL, Bai ST: Study on CXCR4 receptor on megakaryocytes and its ligand in bone marrow in children with acute idiopathic thrombocytopenic purpura. Blood 2003, 102(11):65b Ab 3962

62. Gear ARL, Camerine D: Platelet chemokines and chemokine receptors: Linking hemostasis, inflammation, and host defense. Microcirculation 2003, 10:335-59.

63. vonHundelshausen $P$, Peterson F, Brandt E: Platelet-derived chemokines in vascular biology. Thromb Haemost 2007, 97:704-13.

64. Gleissner CA, vonHundelshausen $P$, Ley $K$ : Platelet chemokines in vascular disease. Arterioscl Thromb Vasc Biol 2008, 28:1920-7.

65. Horstman LL, Jy W, Jimenez JJ, Ahn YS: Endothelial microparticles as markers of endothelial dysfunction [Review]. Frontiers in Bioscience 2004, 9:1118-35

66. Horstman LL, Jy W, Bidot CJ, Ahn YS, Kelley RE, Zivadinov R, Maghzi AH, Etemadifar M, Mousavi AS, Minagar A: Antiphospholipid antibodies: Paradigm in transition. J Neuroinflammation 2009, 6:1-21.

67. Jimenez J, Jy W, Mauro L, Horstman L, Ahn Y: Elevated endothelial microparticles in thrombotic thrombocytopenic purpura (TTP): Findings from brain and renal microvascular cell culture and patients with active disease. Br J Haematol 2001, 112:81-90.

68. Jimenez JJ, Jy W, Mauro L, Soderland C, Horstman LL, Ahn YS: Endothelial cells release phenotypically and quantitatively distinct microparticles in activation and apoptosis. Thromb Res 2003, 109:175-80.

69. Baltus T, vonHundelshausen P, Mause SF, Buhre W, Rossaint R, Weber C: Differential and additive effects of platelet-derived chemokines on monocyte arrest on inflamed endothelium under flow conditions. $J$ Leukoc Biol 2005, 78:435-41.

70. Subileau EA, Rezale P, Davies HA, Colyer FM, Greenwood J, Male DK Romero IA: Expression of chemokines and their receptors by human brain endothelium: implications for multiple sclerosis. J Neuropathol Exp Neurol 2009, 68:227-40.

71. Szczuchinski A, Losy J: Chemokines and chemokine receptors in multiple sclerosis. Potential targets for new therapies. Acta Neurol Scandia 2007, 115:137-46.

72. Kameyoshi Y, Dorschner A, Mallet Al, Christophers E, Schroder JM: Cytokine RANTES released by thrombin-stimulated platelets is a potent attractant for human eosinophils. J Exp Med 1992, 176:587-92.

73. Nomura S, Uehata S, Saito S, Osumi K, Ozeki Y, Kimura Y: Enzyme immunoassay detection of platelet-derived microparticles and RANTES in acute coronary syndromes. Thromb Haemost 2003, 89:506-12.

74. Mause SF, vonHundelshausen P, Zernecke A, Koenen RR, Weber C: Platelet microparticles, a transcellular delivery system for RANTES promoting monocyte recruitment on endothelium. Arterioscl Thromb Vasc Biol 2005, 25:1512-8

75. vanVeen T, Nielsen J, Berkhof J, Barkhof F, Kamphorst W, Bo L, Ravid R, Verweij CL, Huitinga J, Polman CH, Uitdehaag BM: CCL5 and CCR5 genotypes modify clinical, radiological and pathological features of multiple sclerosis. J Neuroimmunol 2007, 190:157-64.

76. Ubogu EE, Callahan MK, Tucky BH, Ranschoff RM: Determination of CCL5driven mononuclear cll migration across the blood-brain barrier. Implications for therapeutic modulation of neuroinflamation. J Neuroimmunol 2006, 179:132-44.

77. Ubogu EE, Callahan MK, Tucky BH, Ranschoff RM: CCR5 expression on mononuclear and T cells: modulation by transmigration across the blood-brain barrier in vitro. Cell Immunol 2006, 243:19-29.

78. Jalosinski M, Karolczak M, Mazurek A, Glabinski A: The effects of methylprednisolone and mitroxantrone on CCL5-induce migration of lymphocytes in multiple sclerosis. Acta Neurol Scand 2008, 118:120-5.

79. Merritt JR, Liu J, Quadros E, Morris ML, Liu R, Zhang R, Jacob B, Postelnek J, Hicks CM, Chen W, Kimble EF, Rogers WL, O'Brien L, et al: Novel 
pyrrolidone urease as C-C chemokine receptor 1 (CCR1) antagonist. J Med Chem 2009.

80. Proudfoot AE, deSouza AL, Muzio Y: The use of chemokine antagonists in EAE models. J Neuroimmunol 2008, 198:27-30.

81. Zheng Y, Gu B, Ji X, Ding X, Song C, Wu F: Sinomedine, an antirheumatic alkaloid, ameliorates clinical signs of disease in the Lewis rat model of acute experimental autoimmune encephalomyelitis. Biol Pharm Bull 2007, 30:1438-44.

82. Vollmar P, Nessler S, Kalluri SR, Hartung HP, Hemmer B: The antidepressant venlafaxine ameliorates murine experimental autoimmune encephalomyelitis by suppression of pro-inflammatory cytokines. Int J Neuropsychopharacol 2009, 12:525-36.

83. Nath N, Khan M, Paintlia MK, Hoda MN, Giri S: Metformin attentuates the autoimmune disease of the central nervous system in animal models of multiple sclerosis. J Immunol 2009, 182:8005-14.

84. Klesney-Tait J, Turnbull IR, Colonna M: The TREM receptor family and signal integration. Nat Immunol 2006, 7:1266-73.

85. Ford JW, McVicar DW: TREM and TREM-like receptors in inflammation and disease. Curr Opin Immunol 2009, 21:38-46.

86. Giomarelli B, Washington VA, Chisolm MM, Quigley L, McMahon JB, More T, McVicar DW: Inhibition of thrombin-induced platelet aggregation using single-chain Fv antibodies specific for TREM-like transcript-1. Thromb Haemost 2007, 97:955-63.

87. Nurden AT, Nurden P, Bermejo E, Combrie R, McVicar DW, Washington VA: Phenotypic heterogeneity in the Gray platelet syndrome extends to the expression of TREM family member, TLT-1. Thromb Haemost 2008, 100:45-51

88. Haselmayer P, Grosse-Hovest L, vanLandenberg P, Schild H, Radsak MP: TREM-1 ligand expression on platelets enhances neurophil activation. Blood 2007, 110:1029-35.

89. Sanchais BS, Higazi AA, Cines DB, Poncz M, Kowalska MA: Interaction of platelet factor 4 with the vessel wall. Semin Thromb Hemost 2004, 30:351-8.

90. Mixon TA, Dehmer GJ: Recombinant platelet factor 4 for heparin neutralization. Semin Thromb Hemost 2004, 30:369-77.

91. Warkentin TE: An overview of heparin-induced thrombocytopenia syndrome [Theme issue]. Semin Thromb Hemost 2004, 30:273-83.

92. Arnout J: The pathogensis of the anti-phospholipid syndrome: A hypothesis based on parallelisms with heparin-induced thrombocytopenia. Thromb Haemost 1996, 75:536-41.

93. Anitua E, Andia I, Ardanza B, Nurden P, Nurden AT: Autologous platelets as a source of proteins for healing and tissue regeneration. Thromb Haemost 2004, 91:4-15.

94. Nurden AT, Nurden P, Sanchez M, Andia I, Anitua E: Platelets and wound healing. Front Biosci 2008, 1:3532-48.

95. Rozman P, Bolta Z: Use of platelet growth factors in treating wounds and soft-tissue injuries. Acta Dermatovenerol Alp Panonica Adriat 2007, 16:155-65

96. Loppnow H, Bil R, Hirt S, Schonbeck U, Herzberg M, Werdan K, Rietschel ET, Brandt E, Flad HD: Platelet-derived interleukin-1 induces cytokine production, but not proliferation of human vascular smooth muscle cells. Blood 1998, 91:134-41.

97. Hawrylowicz CM, Howells GL, Feldmann M: Platelet-derived interleukin 1 induces human endothelial adhesion molecule expression and cytokine production. J Exp Med 1991, 174:785-90.

98. Elzey BD, Tian J, Jensen RJ, Swanson AK, Lees JR, Lentz SR, Stein CS, Nieswandt B, Wang Y, Davidson BL, Ratliff TL: Platelet-mediated modulation of adaptive immunity: A communication link between innate and adaptive immune comparments. Immunity 2003, 19:9-19.

99. Czapiga M, Kirk AD, Lekstrom-Himes L: Platelets deliver costimulatory signals to antigen-presenting cells: a potential bridge between injury and immune activation. Exp Hematol 2004, 32:135-9.

100. Sprague DL, Sowa JM, Elzey BD, Ratiff TL: The role of platelet CD154 in the modulation of adaptive immunity. Immunol Res 2007, 39:185-93.

101. Martinson J, Bae J, Klingemann HG, Tam Y: Activated platelets rapidly upregulate CD40L expression and can effecively mature and activate autologous ex vivo differentiated DC. Cytotherapy 2004, 6:487-97.

102. Nguyen XD, Muller-Berghaus J, Kalsch T, Schadendorf D, Borggrefe M, Kluer $\mathrm{H}$ : Differentiation of monocyte-derived dendritic cells under the influence of platelets. Cytotherapy 2008, 10(7):720-9.
103. Hamzeh-Cognasse H, Cognasse F, Palle S, Chavarin P, Olivier T, Delazay O, Pozzetto B, Garraud O: Direct contact of platelets and their release products exert differential effects on human dendritic cell maturation. BMC Immunol 2008, 25:54.

104. Chitnis T, Khoury SJ: Role of costimulatory pathways in the pathogenesis of multiple sclerosis and experimental autoimmune encephalomyelitis. J Allergy Clin Immunol 2003, 112:837-49.

105. Benveniste EN, Nguyen VT, Wesemann DR: Molecular regulation of CD40 gene expresson in macrophages and microglia. Brain Behav Immun 2004, 18:7-12.

106. Allen SD, Rawale SV, Whitacre CC, Kaumaya PT: Therapeutic peptidomimetic strategies for autoimune disease: costimulation blockade. J Pept Rs 2005, 65:591-604.

107. Levesque MC: Translational Mini-Review Series on B Cell-Directed Therapies: recent advancs in B cell-directed biological therapies for autoimmune disorders. Clin Exp Immunol 2009, 157:198-208.

108. Filion LG, Matusevicius D, Graziani-Bowering GM, Kumar A, Freedman MS: Monocyte-derived IL12, CD88 (B7-2) and CD40L expression in relapsing and progressive multiple sclerosis. Clin Immunol 2003, 106:127-38.

109. Harp CT, Lovett-Racke AF, Racke MK, Frohman EM, Monson NL: Impact of myelin-specific antigen presenting B cells on T cell activation in multiple sclerosis. Clin Immunol 2008, 28(3):382-91.

110. Santilli F, Basili S, Ferroni P, Davi G: CD40/CD40L system and vascular disease. Intern Emerg Med 2007, 2:256-68.

111. Ahn ER, Lander G, Jy W, Bidot C, Jimenez JJ, Horstman LL, Ahn YS: Differences of soluble CD40L in sera and plasma: Implications on CD40L assay as a marker of thrombotic risk. Thromb Res 2004, 114:143-8.

112. Myong S, Cui S, Cornish PV, Kirchofer A, Gack MU, Jung JU, Hopfner K, Taekjip H: Cytosolic viral sensor RIG-1 is a 5'-triphosphate-dependent translocase on double-stranded RNA. Science 2009, 323:1070-4

113. Roberts TL, Idris A, Dunn JA, Kelly GM, Burnton CM, Hodgson S, Hardy LL, Garceau V, Sweet MJ, Ross IL, Hume DA, Stacey KJ: HIN-200 proteins regulate caspase activation in response to foreign cytoplasmic DNA. Science 2009, 323:1057-60.

114. Shiraki R, Inoue N, Kawasaki S, Takei A, Kadotani M, Ohnishi U, Ejiri J, Kobayashi S, Hirata K, Kawashima S, Yokoyama M: Expression of Toll-like receptors on human platelets. Thromb Res 2004, 113:375-85.

115. Cognasse F, Hamzeh H, Chavarin P, Acquart S, Genin C, Garraud O: Evidence of Toll-like receptor molecules on human platelets [Brief Communication]. Immunol Cell Biol 2005, 83:196-8.

116. Cognasse F, Hamzeh-Cognasse H, Lafarge S, Delezay O, Pozzetto B, McNicol A, Garraud O: Toll-like receptor 4 ligand can differentially modulate the release of cytokines by human platelets. $\mathrm{Br} J$ Haematol 2008, 141:84-91.

117. Cognasse F, Hamzeh-Cognasse H, Garraud O: Platelets "Toll-like receptor" engagement stimulates the release of immunomodulatory molecules [French]. Transfus Clin Biol 2008, 15:139-47.

118. Chearwae W, Bright JJ: 15-deoxy-Delta (12,14)-prostaglandin J(2) and curcumin modulate the expression of toll-like receptors 4 and 9 in autoimmune T lymphocytes. J Clin Immunol 2008, 28:558-70.

119. Drew PD, Xu J, Racke MK: PPAR gamma: Therapeutic potential for multiple sclerosis. PPAR Res 2008, 2008:627463.

120. Xu J, Racke MK, Drew PD: Peroxisome proliferator-activated receptoralpha agonist fenofibrate regulates IL-12 family cytokine expression in the CNS: relevance to multiple sclerosis. J Neurochem 2007, 103(5):1801-10.

121. Bright JJ, Walline CC, Kanakasabai S, Chakraborty S: Targeting PPAR as a therapy to treatmultiple sclerosis. Expert Opin Ther Targets 2008, 12(12):1565-75.

122. Heneka MT, Landreth GE: PPARs in the brain. Biochim Biophys Acta 2007, 1771(8):1031-45

123. Mrak RE, Landreth GE: PPARgamma, neuroinflammation and disease. $J$ Neuroinflammation 2004, 1:5.

124. Kummer MP, Heneke MT: PPARs in Alzheimer's disease. PPAR Res 2008, 2008:403896.

125. Chaturvedi RK, Beal MF: PPAR: a therapeutic target in Parkinson's disease. J Neurochem 2008, 106:506-18.

126. Yang Y, Gocke AR, Lovett-Racke A, Drew PD, Rcke MK: PPAR alpha regulation of the immune response and autoimmune encephalomyelitis. PPAR Res 2008, 2008:546753. 
127. Lleo A, Galea E, Sastre M: Molecular targets of non-steroidal antiinflammatory drugs in neurodegtenerative diseases. Cell Mol Life Sci 2007 64:1402-18.

128. Panchatcharam M, Miriyala S, Yang F, Rojas M, End C, Vallant C, Dong A, Lynch K, Chun J, Morris AJ, Smyth SS: Lysophosphatidic acid receptors 1 and 2 play roles in regulation of vascular injury responses but not blood pressure. Circ Res 2008, 103:662-70.

129. Mestre J, Docagne F, Correa F, Loria F, Hernangomez M, Borrell J, Guazo C: A cannabinoid agonist interferes with the progression of a chronic model of multiple sclerosis by downregulating adhesion molecules. $\mathrm{Mol}$ Cell Neurosci 2009, 40:258-66.

130. Klotz L, Diehl L, Dani J, Neumann H, vonOppen N, Dolf A, Endl E, Klockgether T, Engelhardt B, Knolle P: Brain endothelial PPAR gamma controls inflammation induced CD4+ $\mathrm{T}$ cell adhesion and transmigration in vitro. J Neuroimmunol 2007, 190:34.

131. Spinelli SL, O'Brien JJ, Bancos S, Lehmann GW, Springer DL, Blumberg N Francis CW, Taubman MB, Phipps RP: The PPAR-platelet connection: modulators of inflammation and potential cardiovascular effects [Article ID\#328172]. PPAR Res 2008, 2008:1-16.

132. Shimizu T: Lipid mediators in health and disease: enzyms and receptors as therapeutic targets for the regulatio of immunity and inflammation. Annu Rev Pharmacol Toxicol 2009, 49:123-50.

133. Farooqui AA: Lipid mediators in the neural cell nucleus: Their metabolism, signaling, and association with neurological diseases. Neuroscientist 2009, 15:392-407.

134. Gardell S, Dubin AE, Chun J: Emerging medicinal roles for lysophospholipid signaling. Trends Molec Med 2006, 12(2):65-75.

135. Morris AJ, Panchatcharam M, Cheng HY, Federico L, Fulkerson Z, Selim S, Miriyala S, Escalante-Alcalde D, Smyth SS: Regulation of blood and vascular cell function by bioactive lysophospholipids. JThromb Haemost 2009, 7(Supl1):38-43

136. Chun J, Rosen H: Lysophospholipid receptors as potential targets in tissue transplantation and autoimmune diseases. Curr Pharm Des 2006, 12:161-71

137. Herr DR, Chun J: Effects of LPA and S1P on the nervous system and implications for their involvement in disease. Curr Drug Targets 2007, 8:155-67.

138. Massberg S, vonAdrian UH: Fingolimod and sphingosine-1-phosphate: modifiers of lymphocyte migration. New Engl J Med 2006, 355(Sep 14):1088-91.

139. Kappos L, al e: Oral fingolimod (FTY720) for relapsing multiple sclerosis [with editorial, p1088-91]. New Engl J Med 2006, 355:1124-40.

140. Pamuklar Z, Federico L, Liu S, Umezu-Goto M, Dong A, Panchatcharam M, Fulerson Z, Berdyshev E, Natarajan V, Fang X, vanMeeteren LA, Moolenaar WH, Mills GB, Morris AJ, Smyth SS: Autotaxin/lysopholipase D and lysophosphatidic acid regulate murine hemostasis and thrombosis. J Biol Chem 2009, 284:7385-94.

141. Durgam G, Virag T, Walker MD, Tsukahara R, Yasuda S, Liliom K, vanMeeteren LA, Moolenaar WH, Wilke N, Siess W, Tigyi G, Miller DD: Synthesis, structure-activity relationships, and biological evaluation of fatty alcohol phosphates as lysophosphatidic acid receptor ligands, activators of PPARgamma, and inhibitors of autotaxin. J Med Chem 2005, 48:4919-30.

142. Li ZG, Yu ZC, Wang DZ, Ju WP, Zhang X, Wu QZ, Wu XJ, Cong HM, Man $\mathrm{HH}$ : Influence of acetylsalicylate on plasma lysophosphatidic acid level in patients with ischemic cerebral vascular disease. Neurol Res 2008 30:166-369.

143. Siess W: Platelet interactions with bioactivelipids formed by mild oxidation of low-density lipoprotein. Pathophysiol Haeost Thromb 2006, 35:292-304.

144. Williams JR, Khandoga AL, Goyal R, Fells Jl, Perygin DH, Siess W, Parrill AL, Tigyi G, Fujiwara Y: Unique ligand selectivity of the GPR92/LPA5 lysophosphatidate receptor indicates role in human platelet activation. $J$ Biol Chem 2009, 284:17304-19.

145. Kang S, Yang C, Luo R: LysoPtdOH enhances CXCL16 prodction stiulated by LPS from macrophages and regulate T cell migration. Lipids 2008, 43:1075-83.

146. Eriksson AC, Whiss PA, Nilsson UK: Adhesion of human platelets to albumin is synergistically increasd by lysophosphatidic acid and adrenaline in a donor-dependent fashion. Blood Coagul Fibrinolysis 2006, 17:359-68.
147. Nakasaki T, Tanaka T, Okudaira S, Hirosawa M, Umemoto E, Otani K, Jin S, Bai Z, Hayasaka H, Fukui Y, Aozasa K, Fujita N, Tsuruo T, Ozono K, Aoki J, Miyasaka M: Involvement of the lysophosphatidic acid-generating enzyme autotaxin in lymphocyte-endothelial cell interactions. Am $J$ Pathol 2008, 173:1566-76.

148. Smyth SS, Cheng HY, Miriyala S, Panchatcharam M, Morris AJ: Role of lysophosphatidic acid in cardiovascular pysiology and disease. Biochim Biophys Acta 2008, 1781:563-70.

149. Lin Cl, Chen CN, Lee H: Lysophospholipids increase IL-8 and MCP-1 expression in human umbilical cord vein endothelial cells through as IL1-dependent mechanisms. J Cell Biochem 2006, 99:1216-32.

150. MacKenzie A, Wilson HL, Kiss-Toth E, Dower SK, North RA, Suprenant A: Rapid secretion of interleukin-1ß by microvesicle shedding. Immunity 2001, 8:825-35.

151. Gupta GP, Massague J: Platelets and metastasis revisited: a novel fatty link. Clin Invest 2004, 114:1691-3.

152. Boucharaba A, Serre CM, Gres S, Saulnier-Blache JS, Bordet JC, Gugliemi J, Clezardin R, Peyruchaud O: Platelet-derived lysophosphatidic acid supports the progression of osteolytic bone metastasis in breast cancer. J Clin Invest 2004, 114:1714-25.

153. Pamuklar Z, Lee JS, Cheng HY, Panchatcharam M, Steinhubl S, Morris AJ, Charnigo R, Smyth SS: Individual heterogeneity in platelet response to lysophosphatidic acid: Evidence for a novel inhibitory pathway. Arterioscl Thromb Vasc Biol 2008, 28:555-61.

154. Khandoga AL, Fujiwara Y, Goyal P, Pandey D, Tsukahara R, Bolen A, Guo H, Wilke N, Liu J, Valentine WJ, Durgam GG, Miller DD, Jiang G, Prestwich GD, Tigyi G, Siess W: Lysophosphatidic acid-induced platelet shape change revealed through LPA(1-5) receptor-selective probes and albumin. Platelets 2008, 19:415-27.

155. Loria F, Petrosino S, Mestre L, Spagnolo A, Correa F, Hernangomez M, Guaza C, DiMarzo V, Docagne F: Study of the regulation of the endocannabinoid system in a virus model of multiple sclerosis reveals a therapeutic effect of palmitoyl ethanolamine. Eur J Neurosci 2008, 28:633-542.

156. Moriyama T, Urade R, Kito M: Purification and characterization of diacylglycerol lipase from human platelets. J Biochem 1999, 125:1077-85.

157. Jung KM, Astarita G, Zhu C, Wallace M, Mackie K, Piomelli D: A key role for diacylglycerol lipase-alpha in metabotropic glutamate receptordependent endocannabinoid mobilization. Mol Pharmacol 2007, 72:612-21.

158. Baldassarri S, Bertoni A, Bagarotti A, Sarasso C, Zanfa M, Catani MV, Avigliano L, Maccarrone M, Torti M, Sinigaglia F: The endocannabinoid 2arachidonyl glycerol activates human platelets through non-CB1/CB2 receptors. J Thriomb Haemost 2008, 6:1772-9.

159. Schafer A, Pfrang J, Neumuller J, Fiedler S, Ertl G, Bauersachs J: The cannabinoid receptor-1 antagonist rimonabant inhibits platelet activation and reduces pro-inflammatory chemokines in leukocytes in Zucker rats. Br J Pharmacol 2008, 154:1047-54.

160. Serhan CN, Hong S, Gronert K, Colgan SP, Devchand PR, Mirick G, Moussignac RL: Resolvins: a family of bioactive products of omega-3 fatty acid transformation circuits initiated by aspirin treatment that counter proinflammation signals. J Exp Med 2002, 196:1025-37.

161. Ridker PM: Testing the inflammatory hypothesis of atherosclerosis: scientific rationale for the cardiovascular inflammation reduction trial (CIRT). J Thromb Haemost 2009, 7(supl1):332-9.

162. Poulsen RC, Gotlinger KH, Serhan CN, Kruger MC: Identification of inflammatory and proresolving lipid mediators in bone marrow and their lipidomic profiles with ovariectomy and omega-3 intake. Am J Hematol 2008, 83:437-45.

163. Masoodi M, Mir AA, Petasis NA, Serhan CN, Nicolaou A: Simultaneous lipidomic analysis of three families of bioactive lipid mediators, leukotrienes, resolvins, protectins and related hydroxy-fatty acids by liquid chromatography/electrospray ionisation tandem mass spectrometry. Rapid Commun Mass Spectrom 2008, 22:75-83.

164. Marcheselli VL, Hong S, Lukiw WJ, Tian XH, Gronert K, Musto A, Hardy M, Gimenez JM, Chiang N, Serhan CN, Bazan NG: Novel docosanoids inhibit brain ischemia-reperfusion-mediated leukocyte infiltration and proinflammatory gene expression. J Biol Chem 2003, 278:43807-17.

165. Dona M, Freedman G, Schwab JM, Chiang N, Arita M, Goodarzi A, Cheng G, vonAndrian UH, Serhan CN: Resolvin E1, an EPA-derived mediator in 
whole blood, selectively counter-regulates leukocytes and platelets. Blood 2008, 112:848-55.

166. Yang H, Chen C: Cyclooxygenase-2 in synaptic signaling. Curr Pharm Des 2008, 14:1443-51.

167. Stewart TM, Bowling AC: Polyunsaturated fatty acid supplementation in MS. Int MS J 2005, 12:88-93.

168. vaMeeteren ME, Teunissen CE, Dijkstra CD, vanTol EA: Antioxidants and polyunsaturated fatty acids in multiple sclerosis. Eur J Clin Nautr 2005, 59:1347-61.

169. Minghetti L: Cyclooxygenase-2 (COX-2) in inflammatory and degenerative brain diseases. J Neuropathol Exp Neurol 2004, 63:901-10.

170. James-Krack MR, Sexe RB, Shukla SD: Picomolar platelet activating factor mobilizes $\mathrm{Ca}$ to change platelet shape without activating phopholipase $\mathrm{C}$ or protein kinase C: Simultaneous fluorometric measurements of intracellular free $\mathrm{Ca}$ concentration and aggregation. J Pharm Exper Ther 1994, 271:824-31.

171. Stimler NP, Bloor CM, Hugli TE, Wykle RL, McCall CE, O'Flaherty JT: Anaphylactic action of platelet activating factor. Am J Pathol 1981, 105:64-9.

172. Wardlaw AJ, Moqbel R, Cromwell O, Kay AB: Platelet-activating factor. A potent chemotactic and chemokinetic factor for human eosinophils. J Clin Invest 1986, 78:1701-6.

173. O'Flaherty JT, Wykle RL, Miller CH, Lewis JC, Waite M, Bass DA, McCall CE, DeChatelet LR: 1-O -alkyl-sn-glyceryl-3- phosphorylcholines. A novel class of neutrophil stimulants. Am J Pathol 1981, 103:70-9.

174. Braquet $P$, Touqui $L$, Shen TY, BB V: Perspectives in platelet activating factor research. Pharm Rev 1987, 39:97-145.

175. Braquet $P$ : The ginkgolides: Potent platelet-activating factor antagonists isolated from Ginkgo biloba L.: Chemistry, pharmacology and clinical applications. Drugs of the Future 1987, 12:643-99.

176. Farooqui AA, Ong WY, Horrocks LA: Inhibitors of brain phospholipase A2 activity: their neuropharmacological effects and therapeutic importance for the treatment of neurologic disorders. Pharm Rev 2006, 58:591-620,

177. Kihara Y, Yanagida K, Masago K, Kita Y, Hishikawa D, Shindou H, Ishii S, Shimizu T: Platelet-activating factor production in the spinal cord of experimental allergic encephalomyelitis mice via the group IVA cytosolic phospholipase A2-Iyso-PAFAT axis. J Immunol 2008, 181:5008-14.

178. Edwards $\sqcup$, Constantinescu CS: Platelet activating factor/platelet activating factor receptor pathways as a potetial therapeutic target in autoimmune diseases. Inflamm Allergy Drug Targets 2009, 8:182-90.

179. Iwamoto S, Kawasaki T, Kambayashi J, Ariyoshi H, Monden M: Platelet microparticles: A carrier of platelet-activating factor?. Biochem Biophys Res Com 1996, 218:940-4.

180. Mitsios WV, Vini MP, Stengel D, Ninio E, Tselepis AD: Human platelets secrete the plasma type of platelet activating acetylhydrolase primarily associated with microparticles. Arterioscl Thromb Vasc Biol 2006, 26:1907-13.

181. Tselepsis AD, Dentan C, Karabina SAP, Chapman MJ, Ninio E: PAFdegrading acetylhydrolase is preferentially associated with dense LDL and VHDL-1 in human plasma. Arterioscler Thromb Vasc Biol 1995, 15:1764-73.

182. Coeffier E, Danielle J, Prevost MC, Vargaftig BB: Platelet-leukocyte interaction: Activation of rabbit platelets by FMLP-stimulated neutrophils. Br J Pharmacol 1987, 92:393-406.

183. Knezevic II, Predescu SA, Neamu RF, Gorovoy MS, Knezevic NM, Easington C, Malik AB, Predescu DN: Tiam1 and Rac1 are required for platelet-activating factor-induced endothelial junctional disassembly and increase in vascular permeability. J Biol Chem 2009, 284:5381-94.

184. Adamson RH, Ly JC, Sarai RK, Lenz JF, Altangerel A, Drenckhahn D, Curry FE: Epac/Rap1 pathway regulates microvascular hyperpermeability induced by PAF in rat mesentery. Am J Physiol Heart Circ Physiol 2008, 294: H1188-H96.

185. Jiang J, Wen K, Zhou X, Schwegler-Berry D, Castranova V, He P: Threedimensional localization and quantification of PAF-induced gap formation in intact venular microvessels. J Biol Chem 2009, 284:5381-94.

186. Brkovic A, Sirois MS: Vascular permeability induced by VEGF family members in vivo: role of endogenous PAF and NO synthesis. I Cell Biochem 2007, 100:727-37.

187. Bate C, Rumbold L, Williams A: Cholesterol synthesis inhibitors protect against platelet activating factor-induced neuronal damage. J Neurioinflammation 2007, 18:5.
188. Tramontano AF, O'Leary J, Black AD, Muniyappa R, Cutaia MV, ElSherif N: Statin decreases endothelial microparticle release from human coronary artery endothelial cells: implication for the Rho-kinase pathway. Biochem Biophys Res Com 2004, 320:34-8.

189. Osoegawa M, Niino M, Ochi H, Kikuchi S, Murai H, Fukazawa T, Minohara M, Tashiro K: Platelet-activating factor acetylhydrolase gene polymorphism and its activity in Japanese patients with multiple sclerosis. J Neuroimmunol 2004, 150:150-6.

190. Osoegawa M, Miyagishi R, Ochi H, Nakamura I, Niino M, Kikuchi S, Murai $H$ Fukazawa T, Minohara M, Tashiro K, Kira : Platelet-activating factor receptor gene polymorphism in Japanese patients with multiple sclerosis. J Neuroimmunol 2005, 161:195-8

191. Lock C, Hermans G, Redotti R, Brendoland A, Schadt E, Garren H, LangerGould A, Strober S, Cannell B, Allard J, Klonowski P, Austin AA, et al: Genemicroarray analysis of multiple sclerosis lesions yields new targets validated in autoimmune encephalomyelitis. Nature Med 2002, 8:500-8.

192. Kihara Y, Ishii S, Kita Y, Toda A, Shimada A, Shimizu T: Dual phase regulation of experimental allergic encephalomyelitis by platelet activating factor. J Exp Med 2005, 202:853-63.

193. Callea L, Arese M, Orlandini A, Bargnani S, Priori A, Bussolino F: Platelet activating factor is elevated in cerebral spinal fluid and plasma of patients with relapsing-remitting multiple sclerosis. J Neuroimmunol 1999, 94:212-21.

194. Meade CJ, Heuer H, Kempe R: Biochemical pharmacology of platelet activating factor (and PAF antagonists) in relation to clinical and experimental thrombocytopenia. Biochem Pharm 1991, 41:657-68.

195. Lindsberg PJ, Hallenbeck JM, G GF: Platelet activating factor in stroke and brain injury (Review). Ann Neurol 1991, 30:117-29.

196. Duran WN, Milazzo VJ, Sabido F, Hobson RW: Platelet-activating factor modulates leukocyte adhesion to endothelium is ischemia-reperfusion. Microvasc Res 1996, 51:108-15.

197. Osborn TM, Dahlgren C, Hartwig JH, Stossel TP: Modifications of cellular responses to lysophosphatidic acid and platelet-activating factor by plasa gelsolin. Am J Physiol Cell Pysiol 2007, 292:C1323-C30.

198. Cortes-Canteli M, Strickland S: Fibrinogen, a possible key player in Alzheimer's disease. JThromb Haemost 2009, 7(s1):146-50.

199. Ryu J, Davalos D, Akassoclou K: Fibrinogen signal transduction in the central nervous system [Annual Supplment, "State of the Art"]. J Thromb Haemost 2009, 7(s1):151-4.

200. Marlar RA: The protein C system - how complex is it?. Thromb Haemost 2001, 85:756-7.

201. Matthay MA: Severe sepsis: a new treatment with both anticoagulant and anti-inflammatory properties. New Engl J Med 2001, 344:759-62.

202. Bernard GR, Vincent JL, Laterre PF, LaRosa SP, Dhainaut JF, LopezRodriguez A, Steingrub JS, Garber GE, Hildebrand JD, Ely EW, FisherJr CJ: Efficacy and safety of recombinant human activated protein $\mathrm{C}$ for severe sepsis. New Engl J Med 2001, 344:699-709.

203. Han MH, Hwang SI, Roy DB, Lundgren DH, Price JV, Ousman SS, Fernald CH, Gerlitz B, Robinson WH, Baranzini SE, Grinnell BW, Raine CS, Sobel RA, Han DK, Steinman L: Proteomic analysis of active mulctiple sclerosis lesions reveals therapeutic targets. Nature 2008, 451:1076-81.

204. Genc K: Activated protein C: possible therapeutic implications for multiple sclerosis. Med Hypotheses 2007, 68:710.

205. Hagiwara S, Iwasaki W, Matsumoto S, Hasegawa A, Yasuda N, Noguchi T: In vivo and in vitro effects of the anticoagulant, thrombomodulin, on the inflammatory response in rodent models. Shock 2009.

206. DeLaCadena PA, Wachtfogel YT, Colman RW: Ch 11: Contact activation pathway: Inflammation and coagulation. Hemostasis and Thrombosis Philadelphia: J B LippincottColman R, Hirsh J, Marder VJ, Salzman EW 1994 219-40.

207. Colman RW, Cook JJ, Niewiarowski S: Ch 23: Mechanisms of platelet aggregation. Hemostasis and Thrombosis Philadelphia: J B LippincottColman R, Hirsh J, Marder VJ, Salzman EW 1994, 508-23.

208. Khan MM, Bradford HN, Isordia-Salas I, Liu Y, Wu Y, Espinola RG, Ghebrehiwet B, Colman RW: High-molecular weight kininogen fragments stimulate the secretion of cytokines and chemokines through UPAR, Mac-1, and gC1qR in monocytes. Arterioscler Thromb Vasc Biol 2005, 26:2260-6.

209. Schulze-Topphoff U, Pratt A, Prozorovsky T, Siffrin V, Paterka M, Herz J, Bendix I, Ifergan I, Schadock I, Mori MA, VanHorssen J, Schroter F, et al: 
Activation of kinin receptor B1 limits encephalitogenic T lymphocyte recruitment to the central nervous system. Nature Med 2009, 15:788-93.

210. Sainz IM, Pixley RA, Colman RW: Fifty years of research on the plasma kallikrein-kinin system: From protein structure and function to cell biology and in-vivo pathophysiology. Thromb Haemost 2007, 98:77-83.

211. Thone-Reineke C, Steckelinger UM, Ungar T: Angiotensin receptor blockers and cerebral protection in stroke. J Hypteren Suppl 2006, 24:S11-S21.

212. Chavakis T, Santoso S, Clemetson KJ, Sachs UJ, Isordia-Salas I, Paxley RA, Nawroth PP, Colman RW, Preissner KT: High mlecular weight kininogen regulates platelet-leukocyte interaction by bridging Mac-1 and glycoprotein Ib. J Biol Chem 2003, 278:45375-81.

213. Nishimura Y, Shimojima M, Tano Y, Miyamura T, Wakita T, Shimizuzo09 H: Human P-selectin glycoprotein ligand-1 is a functional receptor for enterovirus 71. Nature Med 2009, 15:794-8.

214. Chen D, Dorling A: Critical roles for thrombin in acute and chronic inflammation [in annual supplement, "Stateof the Art"]. J Thromb Haemost 2009, 7(supl1):122-6

215. Blajchman MA, Ozge-Anwar AH: The role of the complement system in hemostasis. Prog Hemat 1986, XIV:149-82.

216. Halkier T: Regulation of blood coagulation (Ch. 8). Mechanisms in Blood Coagulation, Fibrinolysis and the Complement System New York, London: Cambridge Univ. Press 1991.

217. Houle JJ, Leddy JP, Rosenfeld SI: Secretion of the terminal complement proteins C5-C9 by human platelets. Clin Immunol Immunopath 1989, 50:385-93

218. Lachmann PJ: The control of homologous lysis. Imm Today 1991, 12:312-5.

219. Morgan BP, Meri S: Membrane proteins that protect against complement lysis. Spring Sem Immunopath 1994, 15:369-96.

220. Morgan BP: Isolation and characterization of the complement-inhibiting protein CD59 antigen from platelet membranes. Biochem J 1992, 282:409-13.

221. Kim DD, Miwa T, Kimura Y, Schwendener RA, vanCampagne ML, Song WC Deficiency of decay accelerating factor [DAF] and complement receptor 1-related gene/protein y [Crry] on murine platelets leads to complement-dependent clearance by the macrophage phagocytic receptor CRlg. Blood 2008, 112:1109-19.

222. Kim DD, Miwa T, Song WC: Retrovirus-mediated over-expression of decay-acclerating factor rescues Crry-deficient erythrocytes from acute alternative pathway complement attack. J Immunol 2006, 177:5558-66.

223. Miwa T, Zhou L, Kimura Y, Kim D, Bhansoola A, Song WC: Complementdependent T-cell lymphopenia caused by thymocyte deletion of the membrane complement regulator Crry. Blood 2009, 113:2684-1694.

224. Horstman LL, Jy W, Morgan BP, Ahn YS: CD59 expression on platelets in ITP and PNH [at the XXV Congress of ISTH; Cancun, Mexico]. La Revista de Investigacion Clinica (Suppl) 1994, 212:(Abst 110).

225. Navratil JS, Manzi S, Kao AH, Krishnaswami S, Liu CC, Ruffing MJ, Shaw PS, Nilson AC, Dryden ER, Johnson JJ, Ahearn JM: Platelet C4d is highly specific for systemic lupus erythematosus. Athritis Rheum 2008, 54:670-4.

226. Mehta N, Uchino K, Fakhran S, Sattar A, Branstetter BF, Au K, Navratil JS, Paul B, Lee M, Gallagher KM, Manzi S, Ahearn JM, Kao AH: Platelet C4d is associated with acute ischemic stroke and stroke severity. Stroke 2008, 39:3236-41.

227. Roach IT, Rebres RA, Fraser ID, Decamp DL, Lin KM, Sternweis PC, Simon MI, Seaman WE: Signaling and cross-talk by C5a and UDP in macrophages selectively use PLCbeta3 to regulate intracellular free calcium. J Biol Chem 2008, 283:17351-61.

228. Horstman LL, Jy W, Schultz DR, Mao WW, Ahn YS: Complement mediated fragmentation and lysis of opsonized platelets: Gender differences in sensitivity. J Lab Clin Med 1994, 123:515-25.

229. Sims PJ, Wiedmer T: Repolarization of the membrane potential of blood platelets after complement damage: Evidence for a $\mathrm{Ca} 2+-$ dependant exocytotic elimination of C5b-9 pores. Blood 1986, 68:556-61.

230. Sims PJ, Wiedmer T: The response of human platelets to activated components of the complement system. Immunol Today 1991, 12:338-41

231. Butikofer P, Kuypers FA, Xu CM, Chiu DTY, Lubin B: Enrichment of two glycosyl-phosphatidylinositol-achored proteins, acetylcholinesterase and decay accelerating factor, in vesicles released from human red blood cells. Blood 1989, 74:1481-5.
232. Coppinger JA, Cagney G, Toomey S, Kislinger T, Belton O, McRedmond JP, Cahill DJ, Emili A, Fitzgerald DJ, Maguire PB: Characterization of the proteins released from activated platelets leads to localization of novel platelet proteins in human atherosclerotic lesions. Blood 2004, 103:2096-105.

233. Garcia A, Prabhakar S, Hughan S, Anderson TW, Brack CJ, Pearce AC, Dwek RA, Watson SP, Hebestreit HF, Zitzmann N: Differential proteome analysis of TRAP-activated platelets and involvement of DOK-2 and phosphorylation of RGS proteins. Blood 2004, 103:2088-95.

234. Coppinger JA, Maguire PB: Insights into the platelet releasate. Curr Pharm Des 2007, 13:262640-2646.

235. Garcia BA, Smalley DM, Cho H, Shabanowitz J, Ley K, Hunt DF: The platelet microparticle proteome. J Proteome Res 2005, 4:1516-22.

236. Foy M, Maguire PB: Recent advances in the characterization of the platelet membrane system by proteomics [Review]. Curr Pharm Des 2007, 13:2647-55.

237. Bodin S, Viala C, Ragab A, Payrastre B: A critical role of lipid rafts in the organization of a key Fc-gamma-Rlla-mediated signaling pathway in human platelets. Thromb Haemost 2003, 89:318-30.

238. Bodin S, Tronchere H, Payrastre B: Lipid rafts are critical membrane domains in blood platelet activation processes. Biochim Biophys Acta 2003, 1610:247-57.

239. DelConde I, Shrimpton CL, Thiagarajan P, Lopez JA: Tissue-factor-bearing microvesicles arise from lipid rafts and fuse with activated platelets to initiate coagulation. Blood 2005, 106:1604-11.

240. Bugert P, Dugrillon A, Gunaydin A, Eichler H, Kluter H: Messenger RNA profiling in human platelets by microarrary hybridization. Thromb Haemost 2003, 90:738-48.

241. Fink L, Holschermann H, Kwapiszewska G, Muyal JP, Lengermann B, Bohle RM, Santoso S: Characterization of platelet-specific mRNA by realtime PCR after laser-assisted microdissection. Thromb Haemost 2003, 90:749-56

242. McRedmond J: Finding drug targets though analysis of the platelet transcriptome [Review]. Curr Pharm Des 2007, 13:2662-7.

243. McRedmond JP, Park SD, Reilly DF, Coppinger JA, McGuire PB, Shields DC, Fitzgerald DJ: Integration of proteomics in platelets: a profile of platelet proteins and platelet-specific genes. Mol Cell Proteomics 2004, 3:133-44

244. Malaver E, Romaniuk MA, Atri PD, Pozner RG, Negrotto S, Benzadon R, Schattner M: NF kappa B inhibitors impair platelet activation responses. $J$ Thromb Haemost 2009, 7:1333-43.

245. Beaulieu LM, Freedman JE: NFkappaB regulation of platelet function: no nucleus, no genes, no prolem? [Comentary]. J Thromb Haemost 2009, 7:1329-32

246. Roeseler S, Sandrock K, Bartsch T, Zieger B: Septins, a novel group of GTPbinding proteins: relevance in hemostasis, neuopathology and oncogenesis. Klin Pediatr 2009, 221:150-5.

247. Harper AG, Brownlow SL, Sage SO: A role for TRPV1 in agonist-evoked activation of human platelets. J Thromb Haemost 2009, 7:330-8.

248. Goldstein DS, Eisenhofer G, Kopin IJ: Sources and significance of plasma levels of catechols and their metabolites in humans. J Pharmacol Exp Ther 2003, 305:800-11.

249. Stahl SM: Platelets as pharmacologic models for the receptors and biochemistry of monoaminergic neurons (Ch 13). The Platelets New York: Academic PressLongnecker GL 1985, 308-40,

250. Reed GL, Fitzgerald ML, Polgar J: Molecular mechanisms of platelet exocytosis: insights into the "secrete" life of thrombocytes (Review). Blood 2000, 96:3334-42.

251. Lemons PP, Chen D, Bernstein AM, Bennett MK, Whiteheart SW: Regulated secretion in platelets: identification of elements of the platelet exocytosis machinery [see also letter, 92:2191]. Blood 1997, 90:1490-500.

252. Steidl U, Bork S, Schaub S, Selbach O, Seres J, Alvado M, Schroeder T, Rohr UP, Fenk R, Kliszewski S, Maercker C, Neubert P, et al: Primary human CD34+ hematopoietic and progenitor cells express functionally active receptors or neuromediators [and see Editorial pg5-6, "Blood cells: excitable at last"]. Blood 2004, 104:81-8

253. Horstman LL, Esquenazi J, Jy W, Ahn YS: Increased acetylcholinesterase activity of microparticles derived from red cells (RMP) compared to platelets (PMP). Blood 2008, 112:Ab3849. 
254. Kirkpatrick CJ, Bittinger F, Ungar RE, Kriegsmann J, Kilbinger H, IWessler The non-neuronal cholinergic system in the endothelium. Jpn J Pharmacol 2001, 85:24-8.

255. Kawashima K, Fujii T: Basic and clinical aspects of non-neuronal acetylcholine. J Pharmacol Sci 2008, 106:167-73.

256. Wessler I, Kirkpatrick CJ: Acetylcholine beyond neurons: the non-neuronal cholinergic system in humans. Br J Pharmacol 2008, 154:1558-71.

257. Fuji T: An independent, non-neuronal cholinergic system in lymphocytes and its role in regulation of immune function [Japanese]. Nippon Yakurigaku Zasshi 2004, 123:179-88.

258. Jonnakuty C, Gragnoli C: What do we know about serotonin?. J Cell Physiol 2008, 217:301-6.

259. Linder AF, Ni W, Diaz J, Szasz T, Burnett R, Watts SW: Serotonin (5-HT) in veins: not all in vain. J Pharmacol Exp Ther 2007, 323:415-25.

260. Rosen CJ: Serotonin rising. The bone, brain, bowel connection [For comments see issue $11 \mathrm{pg} 2580]$. N Engl J Med 2009, 360:957-9.

261. Soga F, Katoh N, Inoue T, Kishimoto S: Serotonin activates human monocytes and prevents apoptosis. J Invest Dermatol 2007, 127:1947-55.

262. Ciz M, Komrskova D, Pracharova L, Okenkova K, Cizova H, Moravcova A, Jancinova V, Petrikova M, Lojek A, Nosal R: Serotonin modulates the oxidative burst of human phagocytes via various mechansisms. Platelets 2007, 18:583-90

263. Mostert JP, Admiraal-Behloul F, Hoogduin JM, Luyendijk J, Heersema DJ, vanBuchem MA, DeKeyser J: Effects of fluoxetine on disease activity in relapsing multple sclerosis: A double-blind, placebo-controlled exploratory study. J Neurol Neurosurg Psychiatry 2008, 79:1027-31.

264. Brenner B, Harney JT, Ahmed BA, Jeffus BC, Unal B, Mehta JL, Kilic F: Plasma serotonin levels and the platelet serotonin transporter. J Neurochem 2007, 102:206-15.

265. Frankhauser $P$, Baranyai $R$, Ahrens T, Schloss P, Deuschle M, Liederbogen F: Platelet surface P-selectin expression is highly correlated with serotonin transporter density in human subjects. Thromb Haemost 2008, 100:1201-3.

266. Galan AM, Lopez-Vilchez I, Diaz-Ricart M, Navalone F, Gomez E, Gasto C, Escolar G: Serotonergic mechanisms enhance platelet-mediated thrombogenicity. Thromb Haemost 2009, 102:511-9.

267. Abdelmalik N, Ruhé HG, Barwari K, VanDenDool EJ, Meijers JC, Middeldorp S, Büller HR, Schene AH, Kamphuisen PW: Effect of the selective serotonin reuptake inhibitor paroxetine on platelet function is modified by a SLC6A4 serotonin transporter polymorphism. J Thromb Haemost 2008, 6:2168-74

268. Hoffstetter HH, Mossner R, Lesch KP, Linker RA, Toyka KV, Gold R: Absence of reuptake of serotonin influences susceptibility to clinical autoimmune disease and neuroantigen-specific interferon-gamme production in mouse EAE. Clin Exp Immunol 2005, 142:39-44.

269. Velenovska M, Fizar Z: Effects of cannabinoids on platelet serotonin uptake. Addic Biol 2007, 12:158-66.

270. Markianos S, Koutsis S, Evangelopoulos ME, Mandellos D, Karahalios G, Sfagos C: Relationship of CSF neurotransmitter metabolite levels to disease severity and disability in multiple sclerosis. J Neurochem 2009, 108:158-64.

271. Trincavelli ML, Cubano S, Montali M, Santaguida S, Lucacchini A, Martini C: Norepinephrine-mediated regulation of $5 \mathrm{HT} 1$ receptor functioning in human platelets. Neurochem Res 2008, 33:1292-300.

272. Watts SW, Priestley JR, Priestley JM: Serotonylation of vasculart proteins important to contraction. PloS One 2009, 4:e5682.

273. Alberio LJ, Clemetson KJ: All platelets are not equa. Curr Hematol Rep 2004, 3:338-43

274. Sevush S, Jy W, Horstman LL, Mao WW, Kolodny L, Ahn YS: Platelet activation in Alzheimer's disease. Arch Neurol 1998, 55:530-6.

275. Ciabattoni G, Porreca E, DiFebbo C, Dilorio A, Paganelli R, Bucciarelli T, Pescara L, DelRe L, Giusti C, Falco A, Sau A, Patrono C, Davì G: Determinants of platelet activation in Alzheimer's disease. Neurobiol Aging 2007, 28:336-42.

276. Oulhaj A, Refsum H, Beaumont $H$, Williams J, King E, Jacoby R, Smith AD: Homocysteine as a predictor of cognitive decline in Alzheimer's disease. Int J Geriatr Psychiatry 2010, 25:82-90.

277. Lambert JC, Heath S, Even G, Campion D, Sleegers K, Hiltunen M, Combarros O, Zelenika D, Bullido MJ, Tavernier B, Letenneur L, Hiltunen M, et al: Genome-wide association study identifies variants at CLU and CR1 associated with Alzheimer's disease. Nat Genet 2009, 41:1094-9.

278. Harold D, Abraham R, Hollingworth P, Sims R, Gerrish A, Hamshere ML, Pahwa JS, Moskvina V, Dowzell K, Williams A, Jones N, Thomas C, et al: Genome-wide association study identifies variants at CLU and PICALM associated with Alzheimer's disease. Nat Genetics 2009, 41:1088-93.

279. Holmes C, Cunningham C, Zotova E, Woolford J, Dean C, Kerr S, Culliford D, Perry VH: Systemic inflammation and disease progression in Alzheimer disease. Neurology 2009, 73:768-74.

280. Scarmeas N, Luchsinger JA, Schupf N, Brickman AM, Cosentino S, Tang MX, Stern Y: Physical activity, diet, and risk of Alzheimer disease. JAMA 2009, 302:627-37.

281. Féart C, Samieri C, Rondeau V, Amieva H, Portet F, Dartigues JF, Scarmeas N, Barberger-Gateau P: Adherence to a Mediterranean diet, cognitive decline, and risk of dementia. JAMA 2009, 302:638-48.

282. Sizova D, Charbaut E, Delalande F, Poirier F, High AA, Parker F, VanDorsselaer A, Duchesne M, A AD-H: Proteomic analysis of brain tissue from an Alzheimer's disease mouse model by two-dimensional difference gel electrophoresis. Neurobiol Aging 2007, 28:357-70

283. Liao L, Cheng D, Wang L, Duong DM, TG TGL, Gearing M, Rees HD, Lah J, Levey Al, Peng J: Proteomic characterization of postmortem amyloid plaques isolated by laser capture microdissection. J Biol Chem 2004, 279:37061-8.

284. Lesage SR, Mosley TH, Wong TY, Szklo M, Knopman D, Catellier DJ, Cole SR, Klein R, Coresh J, Coker LH, Sharrett AR: Retinal microvascular abnormalities and cognitive decline: the ARIC 14-year follow-up study. Neurology 2009, 73:862-8.

285. Chen M, Inestrosa NC, Ross GS, Fernandez HL: Platelets are the principal cource of amyloid beta peptide in human blood. Biochem Biophyis Res Commun 1995, 213:96-103.

286. Borroni B, Agosti C, Marcello E, DiLuca M, Padovani A: Blood cell markers in Alzheimer's disease: Amyloid precursor protein form ratios in human platelets. Exp Gerontol 2009.

287. Lambert JC, Schraen-Maschke S, Richard F, Fievet N, Rouaud O, Berr C, Dartigues JF, Tzourio C, Alpérovitch A, Buée L, P PA: Association of plasma amyloid beta with risk of dementia: the prospective Three-City Study. Neurology 2009, 73:847-53.

288. Matthew JP, Rinder HM, Smith BR, Newman MF, Rinder CS: Transcerebral platelet activation after aortic cross-clamp release is linked to neurocognitive decline. Ann Thorac Surg 2006, 81:1644-9.

289. Vassar R, Bennett BD, Babu-Khan S, Kahn S, Mendiaz EA, Denis $P$, Teplow DB, Ross S, Amarante P, Loeloff R, Luo Y, Fisher S, Fuller J, Edenson S, Lile J, Jarosinski MA, Biere AL, Curran E, Burgess T, Louis JC, Collins F, Treanor J, Rogers G, Citron M: Beta-secretase cleavage of Alzheimer's amyloid precursor protein by the transmembrane aspartic protease BACE. Science 1999, 286:735-41.

290. Colcianghi F, Marcello E, Borroni B, Zimmerman M, Caltagirone C, Cattabeni F, Padovani A, DiLuca M: Platelet APP, ADAM 10 and BACE alterations in the early stages of Alzheimer's disease. Neurology 2004, 62:498-501.

291. Lammich S, Kojro E, Postina R, Gilbert S, Pfeiffer R, Jasionowski M, Fahrenholz F: Constitutive and regulated alpha-secretase cleavage of Alzheimer's amyloid precursor protein by a disintegrin metalloprotease. PNAS USA 1999, 96:3922-7.

292. Johnston JA, Liu WW, Todd SA, Coulson DT, Murphy S, Irvine GB, Passmore AP: Expression and activity of beta-site amyloid precursor protein cleaving enzyme in Alzheimer's disease. Biochem Soc Trans 2005, 33:1096-100

293. Johnston JA, Liu WW, Coulson DT, Todd S, Murphy S, Brennan S, Foy CJ, Craig D, Irvine GB, Passmore AP: Platelet beta-secretase activity is increased in Alzheimer's disease. Neurobiol Aging 2008, 29:661-8.

294. Hu X, He W, Diacomu C, Tang X, Kidd GJ, Macklin WB, Trapp BT, Yan R: Genetic deletion of BACE1 in mice affects remyelination of sciatic nerves. FASEB j 2008, 22:2970-80.

295. Liu WW, Todd S, Coulson DT, Irvine GB, Passmore AP, McGuiness B, McConville M, Craig D, Johnston JA: A novel reciprocal and biphasic relationship between membrane cholesterol and beta-secretase activity in SH-SY5Y cells and human platelets. J Neurochem 2009, 108:341-9. 
296. Gong X, Xie Z, Zuo H: A new track for understanding the pathogenesis of multiple sclerosis: From the perspective of early developmental deficit caused by the potential 5-HT deficiency in individuals in high latitude areas. Med Hypotheses 2008, 71:580-3.

297. Putnam TJ: Studies in multiple sclerosis (iv) 'encephalitis' and sclerotic plaques produced by venular obstruction. Arch Neurol Neurosurg Psychiat 1935, 33:929-40.

298. Savitsky JP: Platelet adhesiveness in multiple sclerosis. Bull NY Acad Med 2nd Series 1952, 28:462-8

299. Wright HP, Thompson RHS, Zilkha KJ: Platelet adhesiveness in multiple sclerosis. Lancet 1965, 65:1109-10.

300. Sanders H, Thompson RHS, Wright P, Zilkha KJ: Further studies on platelet adhesiveness and serum cholesteryl linoleate levels in multiple scleross. J Neurol Neurosurg Psychiat 1968, 31:321-5.

301. Millar JHD, Merrett JD, Dalby AM: Platelet stickiness in multiple sclerosis. $J$ Neurol Neurosurg Psychiat 1966, 29:187-9.

302. Granier H, Bellard S, Nicholas X, PLaborde J: Association sclerose en plaques et thrombocytopeni auto-immune. Rev Med Interne 2001, 22:1271-7.

303. Munteis E, Segura N, EMartinez J, Quadrado E, Galvez A, Roquer J: Idiopathic thrombocytopeic purpura in patients with multiple sclerosis [Abstract]. Mult Scler 2006, 12:S210.

304. Segal JB, Powe NR: Prevalence of immune thrombocytopenia: Analysis of adminstrative data [see Table 4]. J Thromb Haemost 2006, 4:2377-83.

305. Sheremata WA, Fineberg M, Ahn YS: Association of immune thrombocytopenia and abnormal platelet functions with multiple sclerosis (Abstract). Brain Pathol 1993, 3:293.

306. Sheremata WA, Jy W, Horstman LL, Ahn YS, Alexander JS, Minagar A: Evidence of platelet activation in multiple sclerosis. J Neuroinflammation 2008, 5:27.

307. Kirby S, Brown MG, Muray TJ, Fisk JD, Stadnyk K, MacKinnon-Cameron D, Bhan V: Progression of multiple sclerosis in patients with other autoimmune disorders [P128]; Prevalenceof other autoimmune diseases in patients with multiple sclerosis [P129]. Mult Scler 2005, 11:S28-S9.

308. Minagar A, Jy W, Jimenez JJ, Alexander JS: Multiple sclerosis as a vascular disease. Neurol Res 2006, 28:230-5.

309. Losy J, Niezgoda A, Wender M: Increased serum levels of soluble PECAM1 in multiple sclerosis patients with brain gadolinum-enhancing lesions. J Neuroimmunol 1999, 99:169-72.

310. Minagar A, Jy W, Jimenez JJ, Mauro LM, Horstman LL, Ahn YS, Sheremata WA: Elevated plasma endothelial microparticles in multiple sclerosis. Neurology 2001, 56:1319-24.

311. Kuenz B, Lutterotti A, Khalil M, Ehling R, Gneiss C, Deisenhammer F, Reindl M, Berger T: Plasma levels of soluble adhsion molecules SPECAM1 , sP-selectin and sE-selectin are associated with relapsing/remitting disease course in multiple sclerosis. J Neuroimmunol 2005, 167:143-9.

312. Gumina RJ, Kirschbaum NE, Rao PN, vanTuinen P, Newman PJ: The human PECAM-1 gene maps to 17q23. Genomics 1996, 34:229-32.

313. Sciacca FL, Ferri C, D'Alfonso S, Bolognisi E, Martinelli F, Boneschi F, Cuzzilla B, Colombo B, Comi G, Canal N, Grialdi LM: Association study of a new polymorphism in the PECAM-1 gene in multiple sclerosis. $J$ Neuroimmunol 2000, 104:174-8.

314. Nelissen I, Fiten P, Vandenbroeck K, Hillert J, Olsson T, Marrosu MG, Opdenakker G: PECAM1, MPO and PRKAR1A at chromosome 17q21-q24 and susceptibility for multiple sclerosis in Sweden and Sardinia. Neuroimmunol 2000, 108:153-9.

315. Cognasse F, Hamzeh-Cognasse H, Lafarge S, Chavarin P, Cogne M Richard Y, Garraud O: Human platelets can activate peripheral blood B cells and increase production of immunoglobulins. Exp Hematol 2007, 35:1376-87.

316. Humm AM, Z'Graggen WJ, Bühler R, Magistris MR, Rösler KM: Quantification of central motor conducion deficits in multiple sclerosis patients before and after treatment of acute exacerbations with methylprednisolone. J Neurol Neurosurg Psychiat 2006, 77:345-50.

317. Bidot CJ, Horstman LL, Jy W, Jimenez JJ, Bidot C Jr, Ahn YS, Alexander JS, Gonzalez-Toledo E, Kelley RE, Minagar A: Clinical and neuroimaging correlates of antiphospholipid antibodies in multiple sclerosis. JCM Neurol 2007, 7:36.

318. Blair P, Falumenhaft R: Plateletalpha-granules: basic biology and clinical correlates. Blood Rev 2009, 23:177-89.
319. Lopez-Vilchez I, Diaz-Ricart M, White JG, Escolar G, Galan AM: Serotonin enhances platelet procoagulant properties and their activation induce during platelet tissue factor uptake. Cardiovasc Res 2009.

320. VanGeet C, Izzi B, Labarque V, Freson K: Human latelet pathology related to defects in the G-protein signaling cascade. J Thromb Haemost 2009, 7:282-6.

doi:10.1186/1742-2094-7-10

Cite this article as: Horstman et al.: Role of platelets in

neuroinflammation:

a wide-angle perspective. Journal of Neuroinflammation 2010 7:10

\section{Submit your next manuscript to BioMed Central and take full advantage of:}

- Convenient online submission

- Thorough peer review

- No space constraints or color figure charges

- Immediate publication on acceptance

- Inclusion in PubMed, CAS, Scopus and Google Scholar

- Research which is freely available for redistribution

Submit your manuscript at www.biomedcentral.com/submit 